\title{
Adrenomedullin-Receptor Activity-Modifying Protein 2 System Ameliorates Subretinal Fibrosis by Suppressing Epithelial-Mesenchymal Transition in 201 Age-Related Macular Degeneration
}

\author{
Q22 Masaaki Tanaka, ${ }^{* \dagger}$ Shinji Kakihara, ${ }^{* \dagger}$ Kazutaka Hirabayashi, ${ }^{\dagger}$ Akira Imai, ${ }^{\dagger}$ Yuichi Toriyama, ${ }^{\dagger}$ Yasuhiro Iesato, ${ }^{\dagger}$ \\ Takayuki Sakurai, ${ }^{*}$ Akiko Kamiyoshi, ${ }^{\star}{ }^{\ddagger}$ Yuka Ichikawa-Shindo, ${ }^{*}$ Hisaka Kawate, ${ }^{*}$ Megumu Tanaka, ${ }^{*}$ Nanqi Cui, ${ }^{*}$ \\ Yangxuan Wei, ${ }^{*}$ Yunlu Zhao, ${ }^{*}$ Kohsuke Aruga, ${ }^{*}$ Akihiro Yamauchi, ${ }^{*}$ Toshinori Murata, ${ }^{\dagger}$ and Takayuki Shindo*
}

Q3 From the Departments of Cardiovascular Research* and Ophthalmology, ${ }^{\dagger}$ Shinshu University School of Medicine; and the Department of Life Innovation, ${ }^{\ddagger}$ Institute for Biomedical Sciences, Interdisciplinary Cluster for Cutting Edge Research, Shinshu University, Japan

\author{
Accepted for publication \\ December 17, 2020. \\ Address correspondence to \\ Takayuki Shindo, M.D., Ph.D., \\ Department of Cardiovascular \\ Research, Shinshu University \\ School of Medicine, Asahi 3-1- \\ 1, Matsumoto, Nagano 390- \\ 8621, Japan. E-mail: tshindo@ \\ shinshu-u.ac.jp.
}

\begin{abstract}
Age-related macular degeneration (AMD) is a leading cause of visual impairment. Anti-vascular endothelial growth factor drugs are used to treat AMD, but they may induce subretinal fibrosis. We have focused on adrenomedullin (AM), a vasoactive peptide, and its receptor activity-modifying protein 2, RAMP2, which regulate vascular homeostasis and suppress fibrosis. Herein, the therapeutic potential of the AM-RAMP2 system was evaluated after laser-induced choroidal neovascularization (LI-CNV), a mouse model of AMD. Neovascular formation, subretinal fibrosis, and macrophage invasion were all enhanced in both AM and RAMP2 knockout mice compared with wild-type mice. These pathologic changes were suppressed by intravitreal injection of AM. Comprehensive gene expression analysis of the choroid after LI-CNV with or without AM administration revealed that fibrosis-related molecules, including Tgfb, Cxcr4, Ccn2, and Thbs1, were all down-regulated by AM. In retinal pigment epithelial cells, co-administration of transforming growth factor- $\beta$ and tumor necrosis factor- $\alpha$ induced epithelialmesenchymal transition, which was also prevented by AM. Finally, the effects of transforming growth factor- $\beta$ and CXCR4 inhibitors were assessed, and they eliminated the difference in subretinal fibrosis Q5 between RAMP2 knockout and wild-type mice. These findings suggest the AM-RAMP2 system suppresses subretinal fibrosis in LI-CNV by suppressing epithelial-mesenchymal transition. (Am J Pathol 2021, $\mathbf{\square}$ : 1-17; https://doi.org/10.1016/j.ajpath.2020.12.012)
\end{abstract}

Q6 Age-related macular degeneration (AMD) is a leading cause of blindness, with a global prevalence of about $8.7 \% .^{1}$ It is associated with choroidal neovascularization (CNV), which develops from the choroid to the subretina, where it causes bleeding or oozing, leading to loss of vision in the affected eye. ${ }^{2}$ Because AMD is mitigated by inhibiting vascular endothelial growth factor (VEGF), VEGF is thought to play a key role in CNV formation. Indeed, some patients are able to retain good vision through anti-VEGF therapy, ${ }^{3-5}$ although others develop irreversible visual impairment due to subretinal fibrosis associated with AMD. ${ }^{6-8}$ Moreover, in one cohort study, subretinal fibrosis was not suppressed with anti-VEGF therapy, and subretinal fibrosis developed in $45.3 \%$ of patients within 2 years after starting anti-VEGF therapy. ${ }^{8}$ In addition, tachyphylaxis necessitates increasing numbers of treatments, which increases the economic and physical burden on patients. ${ }^{9}$

Supported by Japan Science and Technology Agency grant-in-aid for Q4 scientific research (KAKENHI), Core Research for Evolutionary Science and Technology, the Japan Agency for Medical Research and Development, SENSHIN Medical Research Foundation grant, Naito Foundation grant, Novartis Foundation for the Promotion of Science grant, Akaeda Medical Research Foundation, Hoyu Science Foundation, Takahashi Industrial and Economic Research Foundation, and Bristol-Myers Squibb research grant (T.S.).

Disclosures: None declared. 
Tanaka et al

Table 1 Primers Used for Real-Time PCR

\begin{tabular}{|c|c|}
\hline Gene & Primer \\
\hline $\begin{array}{l}\text { Mouse Calcrl (CLR) } \\
\text { forward }\end{array}$ & 5'-AGGCGTTTACCTGCACACACT-3' \\
\hline $\begin{array}{l}\text { Mouse Calcrl (CLR) } \\
\text { reverse }\end{array}$ & 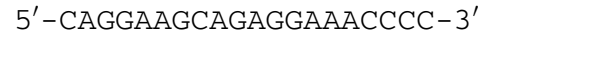 \\
\hline Mouse $A M$ forward & 5'-GGACACTGCAGGGCCAGAT-3' \\
\hline Mouse $A M$ reverse & 5'-GTAGTTCCCTCTTCCCACGACTTA-3' \\
\hline $\begin{array}{l}\text { Mouse Ramp2 } \\
\text { forward }\end{array}$ & 5'-ACTGAGGACAGCCTTGTGTCAAA- $3^{\prime}$ \\
\hline $\begin{array}{l}\text { Mouse } \text { Ramp2 } \\
\text { reverse }\end{array}$ & 5'-CCTTGACAGAGTCCATGCAACTC- $3^{\prime}$ \\
\hline $\begin{array}{l}\text { Mouse Ramp3 } \\
\text { forward }\end{array}$ & 5'-AAAGCCTTCGCTGACATGATG- $3^{\prime}$ \\
\hline $\begin{array}{l}\text { Mouse } \operatorname{Ramp3} \\
\text { reverse }\end{array}$ & 5'-ATCTCGGTGCAGTTAGTGAAGCT-3' \\
\hline $\begin{array}{l}\text { Mouse Tgfb1 } \\
\text { forward }\end{array}$ & $5^{\prime}$-CCCGAAGCGGACTACTATGC- $3^{\prime}$ \\
\hline $\begin{array}{l}\text { Mouse } \operatorname{Tgfb1} \\
\text { reverse }\end{array}$ & 5'-TAGATGGCGTTGTTGCGGT- $3^{\prime}$ \\
\hline $\begin{array}{l}\text { Mouse Tgfb2 } \\
\text { forward }\end{array}$ & 5'-TAAAATCGACATGCCGTCCC-3' \\
\hline $\begin{array}{l}\text { Mouse } \operatorname{Tgfb2} \\
\text { reverse }\end{array}$ & 5'-GAGACATCAAAGCGGACGAT-3' \\
\hline $\begin{array}{l}\text { Mouse } \operatorname{Tgfb3} \\
\text { forward }\end{array}$ & 5'-GATCACCACAACCCACACCT-3' \\
\hline $\begin{array}{l}\text { Mouse } \operatorname{Tgfb3} \\
\text { reverse }\end{array}$ & $5^{\prime}-$ ATAAAGGGGGCGTACACAGC $-3^{\prime}$ \\
\hline $\begin{array}{l}\text { Mouse } C x c r 4 \\
\text { forward }\end{array}$ & 5'-TCAGTGGCTGACCTCCTCTT-3' \\
\hline $\begin{array}{l}\text { Mouse } \mathrm{Cxcr4} \\
\text { reverse }\end{array}$ & 5'-TTTCAGCCAGCAGTTTCCTT-3' \\
\hline $\begin{array}{l}\text { Mouse } \mathrm{Cxcl} 12 \\
\quad \text { (SDF-1) forward }\end{array}$ & 5'-AGAGCCAACGTCAAGCATCT-3' \\
\hline $\begin{array}{l}\text { Mouse } C x c l 12 \\
\quad(S D F-1) \text { reverse }\end{array}$ & 5'-TAATTTCGGGTCAATGCACA-3' \\
\hline $\begin{array}{l}\text { Mouse Thbs1 } \\
\text { forward }\end{array}$ & 5'-CGCCTTCCGCATTGAGAATG-3' \\
\hline $\begin{array}{l}\text { Mouse Thbs1 } \\
\text { reverse }\end{array}$ & 5'-CATCTGCCTCAAGGAAGCCA-3' \\
\hline $\begin{array}{l}\text { Mouse } \mathrm{Ccn} 2 \\
\text { (CTGF) forward }\end{array}$ & $5^{\prime}-$ CAGAGGTGGTGGGGTAGAGA- $3^{\prime}$ \\
\hline $\begin{array}{l}\text { Mouse } \mathrm{Ccn} 2 \\
\text { (CTGF) reverse }\end{array}$ & 5'-CATTGCCACTCACAATGTCC-3' \\
\hline $\begin{array}{l}\text { Mouse Tjp1 (Z0-1) } \\
\text { forward }\end{array}$ & 5'-GCCACTACAGTATGACCATCC- $3^{\prime}$ \\
\hline $\begin{array}{l}\text { Mouse Tjp1 (Z0-1) } \\
\text { reverse }\end{array}$ & 5'-AATGAATAATATCAGCACCATGCC -3' \\
\hline $\begin{array}{l}\text { Mouse Tagln } \\
\text { (SM22 } \alpha) \\
\text { forward }\end{array}$ & 5'-ACCAAAAACGATGGAAACTACCG-3' \\
\hline $\begin{array}{l}\text { Mouse Tagln } \\
(\text { SM22 } \alpha) \\
\text { reverse }\end{array}$ & $5^{\prime}$-CATTTGAAGGCCAATGACGTG - $3^{\prime}$ \\
\hline $\begin{array}{l}\text { Mouse Rhoa } \\
\text { forward }\end{array}$ & $5^{\prime}$-GCTACCAGTATTTAGAAGCCAACCAC-3' \\
\hline $\begin{array}{l}\text { Mouse } R \text { hoa } \\
\text { reverse }\end{array}$ & $5^{\prime}$-GCTGTTAGAGCAGTGTCAGAAGGAC- $3^{\prime}$ \\
\hline
\end{tabular}

(table continues)
Table 1 (continued)

\begin{tabular}{|c|c|}
\hline Gene & Primer \\
\hline $\begin{array}{l}\text { Mouse Rock1 } \\
\text { forward }\end{array}$ & $5^{\prime}-\mathrm{CAAAGCACGCCTAACTGACA}-3^{\prime}$ \\
\hline $\begin{array}{l}\text { Mouse } \text { Rock1 } \\
\text { reverse }\end{array}$ & 5'-TCTGCCTTCTCTCGAGCTTC-3' \\
\hline $\begin{array}{l}\text { Mouse Icam1 } \\
\text { forward }\end{array}$ & 5'-CCTAАAATGACCTGCAGACGG-3' \\
\hline $\begin{array}{l}\text { Mouse } I c m a 1 \\
\text { reverse }\end{array}$ & 5'-TTTGACAGACTTCACCACCCC-3' \\
\hline $\begin{array}{l}\text { Mouse } \mathrm{Ccl} 2 \\
\quad \text { (MCP1) forward }\end{array}$ & 5'-GCAGTTAACGCCCCACTCA-3' \\
\hline $\begin{array}{l}\text { Mouse } \mathrm{Ccl} 2 \\
\text { (MCP1) reverse }\end{array}$ & $5^{\prime}$-ССTACTCATTGGGATCATCTTGCT-3' \\
\hline $\begin{array}{l}\text { Mouse Tnfa } \\
\text { forward }\end{array}$ & $5^{\prime}$-ACGGCATGGATCTCAAAGAC-3' \\
\hline $\begin{array}{l}\text { Mouse } \operatorname{Tnfa} \\
\text { reverse }\end{array}$ & 5'-AGATAGCAAATCGGCTGACG-3' \\
\hline $\begin{array}{l}\text { Mouse Il1b } \\
\text { forward }\end{array}$ & $5^{\prime}$-CTACAGGCTCCGAGATGAACAAC-3' \\
\hline $\begin{array}{l}\text { Mouse } I l 1 b \\
\text { reverse }\end{array}$ & 5'-TCCATTGAGGTGGAGAGCTTTC-3' \\
\hline $\begin{array}{l}\text { Mouse Smad2 } \\
\text { forward }\end{array}$ & 5'-ATGTCGTCCATCTTGCCATTC-3' \\
\hline $\begin{array}{l}\text { Mouse Smad2 } \\
\text { reverse }\end{array}$ & 5'-AACCGTCCTGTTTTCTTTAGCTT-3' \\
\hline $\begin{array}{l}\text { Mouse Smad3 } \\
\text { forward }\end{array}$ & $5^{\prime}$-CATTACCATCCCCAGGTCAC-3' \\
\hline $\begin{array}{l}\text { Mouse Smad3 } \\
\text { reverse }\end{array}$ & 5'-CGTAATTCATGGTGGCTGTG-3' \\
\hline $\begin{array}{l}\text { Human Tgfb1 } \\
\text { forward }\end{array}$ & $5^{\prime}$-GTGGAAACCCACAACGAAAT-3' \\
\hline $\begin{array}{l}\text { Human } T g f b 1 \\
\text { reverse }\end{array}$ & 5'-CGGAGCTCTGATGTGTTGAA-3' \\
\hline $\begin{array}{l}\text { Human } \mathrm{Cxcr} 4 \\
\text { forward }\end{array}$ & $5^{\prime}-\mathrm{CTCCAAGCTGTCACACTCCA-3^{ \prime }}$ \\
\hline $\begin{array}{l}\text { Human } \mathrm{Cxcr} 4 \\
\text { reverse }\end{array}$ & 5'-TCGATGCTGATCCCAATGTA-3' \\
\hline $\begin{array}{l}\text { Human Tjp1 (ZO- } \\
\text { 1) forward }\end{array}$ & $5^{\prime}-$ TCACCTACCACCTCGTCGTCTG-3' \\
\hline $\begin{array}{l}\text { Human Tjp1 (ZO- } \\
\text { 1) reverse }\end{array}$ & 5'-ATGAGCACTGCCCACCCATCT-3' \\
\hline $\begin{array}{l}\text { Human Tagln } \\
\text { (SM22 } \alpha) \\
\text { forward }\end{array}$ & 5'-GATTTTGGACTGCACTTCGC-3' \\
\hline $\begin{array}{l}\text { Human Tagln } \\
\text { (SM22 } \alpha) \\
\text { reverse }\end{array}$ & 5'-GTCCGAACCCAGACACAAGT-3' \\
\hline $\begin{array}{l}\text { Human Rhoa } \\
\text { forward }\end{array}$ & 5'-CTGGTGATTGTTGGTGATGG-3' \\
\hline $\begin{array}{l}\text { Human } R \text { hoa } \\
\text { reverse }\end{array}$ & 5'-GCGATCATAАTCTTCCTGCC-3' \\
\hline $\begin{array}{l}\text { Human Rock1 } \\
\text { forward }\end{array}$ & $5^{\prime}$-AACATGGCATCTTCGACACTC-3' \\
\hline $\begin{array}{l}\text { Human Rock1 } \\
\text { reverse }\end{array}$ & $5^{\prime}-$ CAAAATCACAAAGGCCATGA-3' \\
\hline
\end{tabular}

CLR, calcitonin receptor-like receptor; CTGF, connective tissue growth factor; MCP1, monocyte chemoattractant protein 1; SDF-1, stromal cell-derived factor-1; Z0-1, zonula occludens protein 1 . 


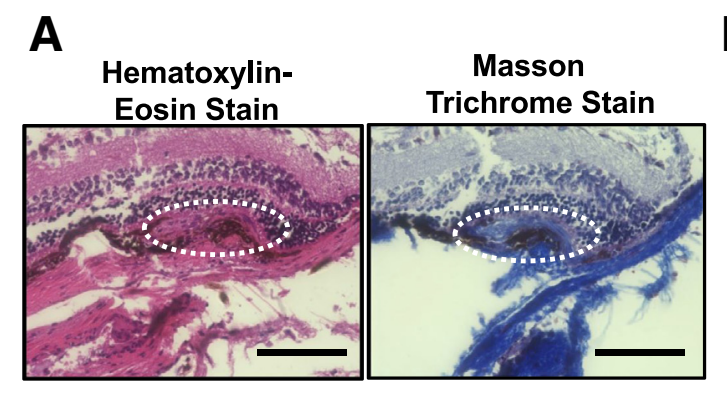

B
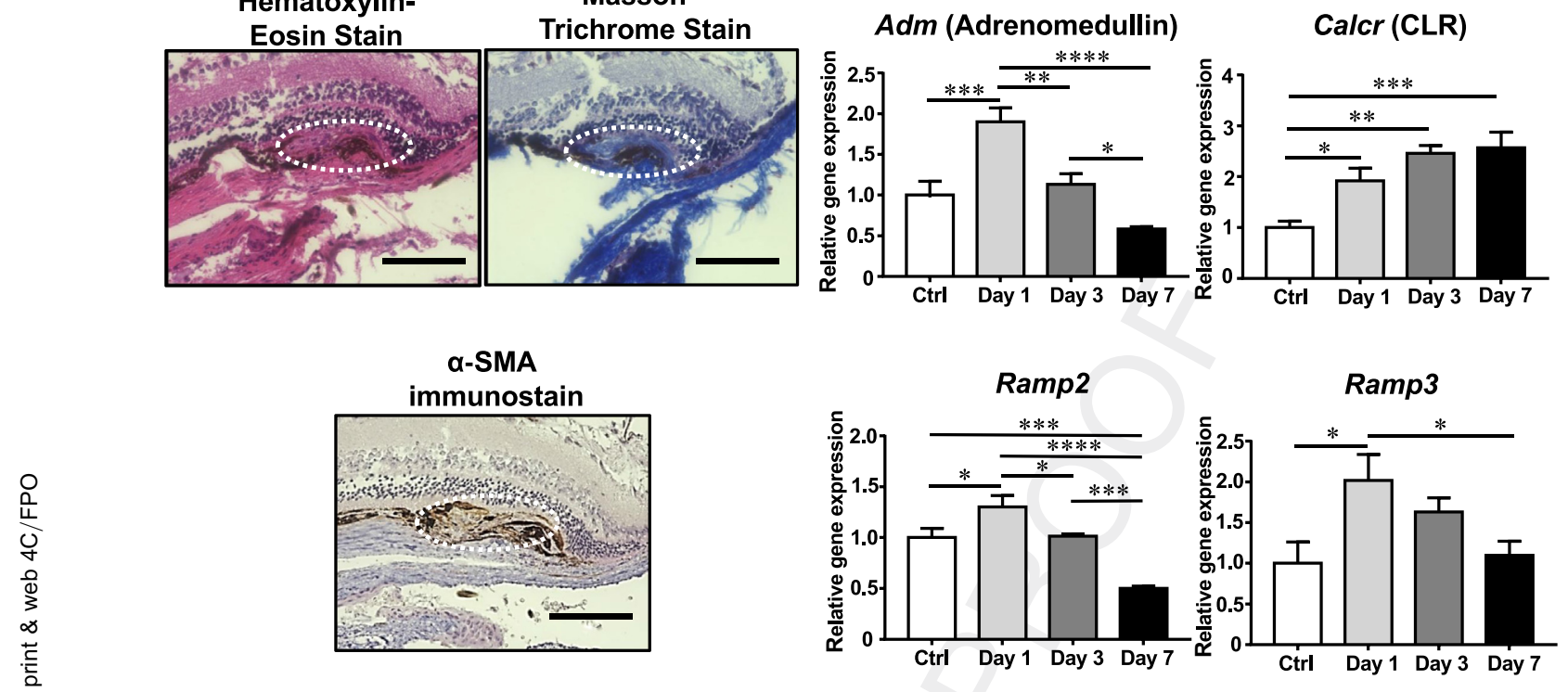

Figure 1 Pathology of the laser-induced choroidal neovascularization (LI-CNV) lesion and expression of adrenomedullin (AM) and its related genes. A: Hematoxylin-eosin staining, Masson trichrome staining, and immunostaining for $\alpha$-smooth muscle actin ( $\alpha$-SMA; diaminobenzidine) in sections of retina from C57BL/6J wild-type (WT) mice 7 days after laser irradiation. Dotted circles show the LI-CNV. Masson trichrome staining and $\alpha$-SMA immunostaining show the subretinal fibrosis in LI-CNV. B: Quantitative real-time PCR analysis of the expression of AM and its related genes in the choroid of untreated C57BL/6J WT mice on days 1,3 , and 7 after the laser irradiation. The mean of the control group without laser irradiation (Ctrl) was assigned a value of 1 . Data are expressed as means \pm SEM (B). $n=5$ to 6 in each group (B). ${ }^{*} P<0.05,{ }^{*} P<<0.01,{ }^{* * *} P<0.001$, and ${ }^{* * * *} P<0.0001$ (one-way analysis of variance with the Tukey test). Scale bars $=100 \mu \mathrm{m}(\mathbf{A})$. CLR, calcitonin receptor-like receptor.

Fibrosis is a pathophysiological response to chronic disorders, a reparative action in damaged organs that is associated with inflammatory responses. ${ }^{10}$ In CNV, hemorrhage and exudative lesions are accompanied by accumulation of extracellular matrix components, such as collagen and Q7 fibrinogen. Infiltration of inflammatory cells, differentiation of retinal pigment epithelial (RPE) cells into fibroblast-like cells via epithelial-mesenchymal transition (EMT), and excessive and poorly ordered extracellular matrix displacement of normal retinal structures, including intramacular and/or surrounding photoreceptor cells. This often results in formation of subretinal fibrovascular tissue. Thus, suppression of fibrosis is an important issue when thinking about the long-term prognosis of AMD patients.

Adrenomedullin (AM) was first identified as a vasodilating peptide isolated from pheochromocytoma. However, subsequent studies revealed that AM exerts a variety of physiological effects and has antioxidative, antiinflammatory, antifibrotic, and antiapoptotic properties. ${ }^{11-13}$ Our group previously reported that homozygous AM knockout (KO) is embryonically lethal because of systemic edema and bleeding, caused mainly by abnormal vascular development. ${ }^{14,15}$ In adults, AM is secreted in the cardiovascular system, where it exerts various vascular effects, ${ }^{14,15}$ and it is now known that AM is also widely expressed in numerous other tissues and organs, including the eyes. ${ }^{16}$ In that regard, using retinal VEGFoverproducing (Kimba) mice, nonobese diabetic model (Akita) mice, and central retinal vein occlusion model mice, our group has shown that AM suppresses pathologic deterioration caused by eye diseases. ${ }^{17,18}$ We reported that AM suppresses retinal inflammation, vascular permeability, and disruption of the blood-retina barrier in Kimba and Akita mice. ${ }^{17}$ Using the central retinal vein occlusion model, we also found that AM improves blood flow by suppressing coagulation, and that by suppressing inflammation and oxidative stress it reduces vascular permeability and retinal edema. ${ }^{18}$ In addition, Yuda et al ${ }^{19}$ reported that, in laserinduced choroidal neovascularization (LI-CNV), a model of AMD, CNV size was significantly greater in heterozygous AM KO than wild-type (WT) mice.

Given these observations, the clinical application of AM has been much anticipated ${ }^{14,20-23}$; however, AM is a peptide with a short half-life in the bloodstream, which limits its usefulness for the treatment of chronic diseases. To overcome that limitation, our group has been focusing on AM's receptor system. AM is a member of the calcitonin superfamily and acts via a G-protein-coupled seventransmembrane domain receptor, calcitonin receptor-like receptor (CLR). ${ }^{24}$ The specificity of CLR for its ligands is regulated by a group of three receptor activity-modifying proteins, RAMP1, RAMP2, and RAMP3. The complex of CLR with RAMP2 or RAMP3 is known to have high affinity for AM. ${ }^{25}$ Interestingly, among homozygous RAMP KO mice, only RAMP2 KO mice die in utero of vascular abnormalities, similar to those observed in homozygous AM KO mice. ${ }^{26}$ This suggests that RAMP2 is the key determinant of the vascular function of AM, and that it may be 


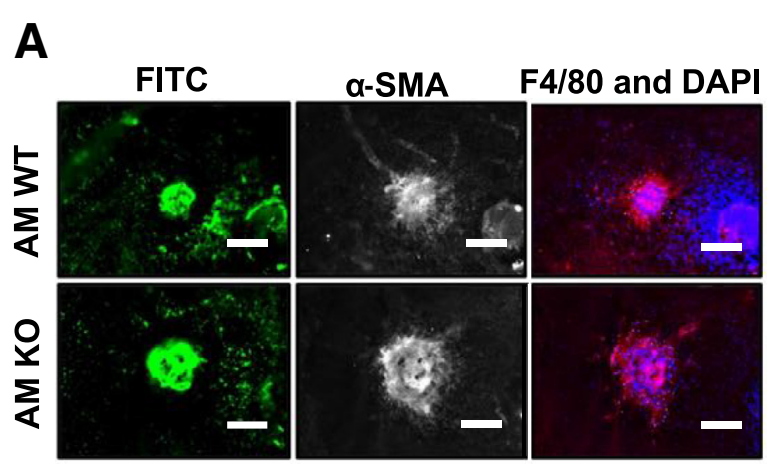

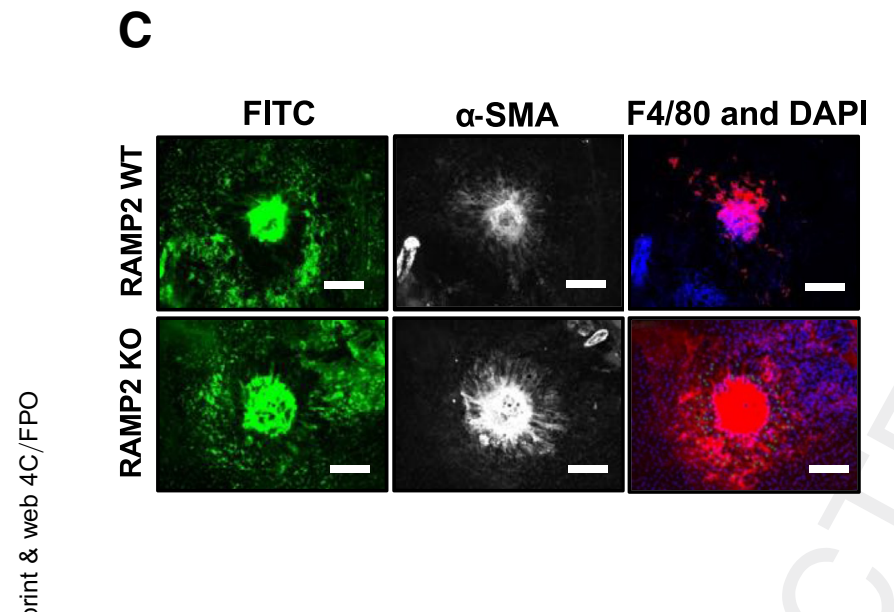
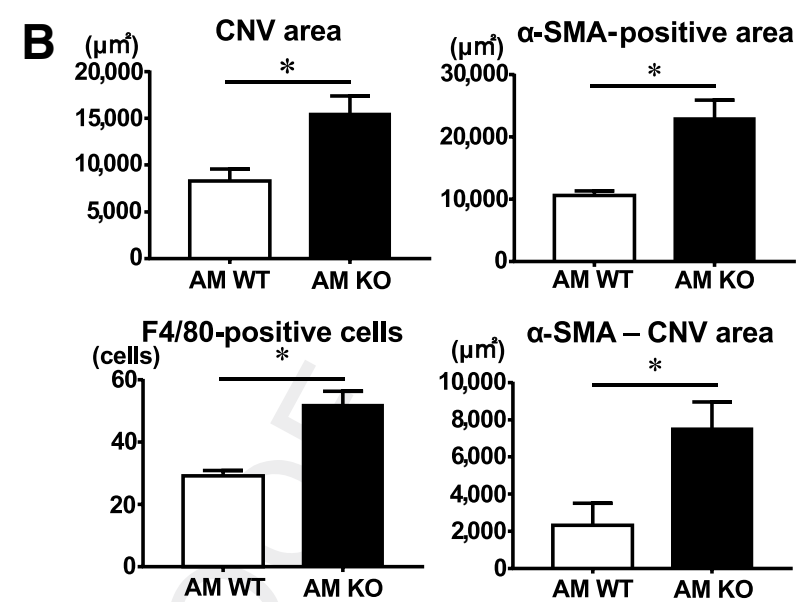

D
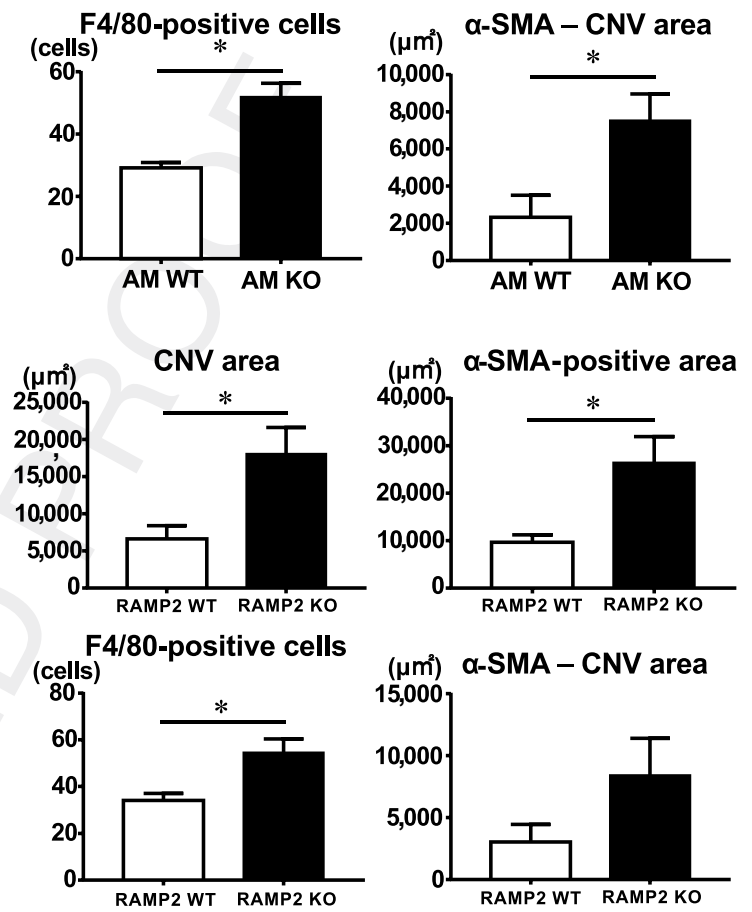

Figure 2 Choroidal flat mount analysis of laser-induced choroidal neovascularization (LI-CNV), fibrosis, and macrophage invasion in adrenomedullin (AM) knockout (KO) and RAMP2 KO mice. A: Comparison of LI-CNV between AM KO and wild-type (WT) mice. On day 7 after laser-induced injury to the Bruch membrane, choroidal flat mounts were prepared, the areas of the fluorescein isothiocyanate (FITC)-positive CNV and $\alpha$-smooth muscle actin ( $\alpha$-SMA)immunopositive fibrotic areas were measured, and the number of F4/80-positive macrophages were counted. B: Bar graphs comparing CNV and fibrotic areas and macrophage invasion between AM KO and WT mice. C: Comparison of LI-CNV between RAMP2 KO and WT mice. D: Bar graphs comparing the CNV and fibrotic areas and macrophage invasion between RAMP2 K0 and WT mice. Data are given as means \pm SEM (B and $\mathbf{D}) . n=10$ in WT mice (B and $\mathbf{D}) ; n=11$ in AM K0 mice (B); $n=14$ in RAMP2 K0 mice (D). ${ }^{*} P<0.05$ ( $t$-test). Scale bars $=100 \mu \mathrm{m}$ (A and $\left.\mathbf{C}\right)$.

possible to modulate the vascular function of AM by modulating RAMP2. In the present study, subretinal fibrosis was analyzed in LI-CNV model mice, and the possibility that the AM-RAMP2 system could serve as a therapeutic target for subretinal fibrosis associated with AMD was evaluated.

\section{Materials and Methods}

\section{Animals}

AM, RAMP2, and RAMP3 KO mice were generated by our group previously. ${ }^{15,26,27}$ In this study, because of the embryonic lethality of homozygous $\mathrm{KO}$, we used heterozygous KO of AM and RAMP2, which reduced expression of these genes to about half that in WT mice. We used homozygous RAMP3 KO mice, as loss of RAMP3 is not lethal, and adult mice are available. Male mice, aged 9 to 12 weeks, were used. WT littermates from each KO line were used as control mice.

Before the procedure, mice were anesthetized by i.p. injection of a mixture of $0.3 \mathrm{mg} / \mathrm{kg}$ medetomidine (Nippon Zenyaku Kogyo Co Ltd, Koriyama, Japan), $4.0 \mathrm{mg} / \mathrm{kg}$ midazolam (Astellas Pharma Inc., Tokyo, Japan), and 5.0 $\mathrm{mg} / \mathrm{kg}$ butorphanol (Meiji Seika Pharma Co Ltd, Tokyo, Japan).

All animal handling complied with protocols approved by the Ethics Committee of Shinshu University School of Medicine. All experiments were performed according to the statements of the Society of Vision and Ophthalmology on the use of animals in ophthalmic and visual research and our institutional guidelines.

\section{Indocyanine Green Angiography}

Before the experiments described below, indocyanine green angiography, using a confocal scanning-laser 

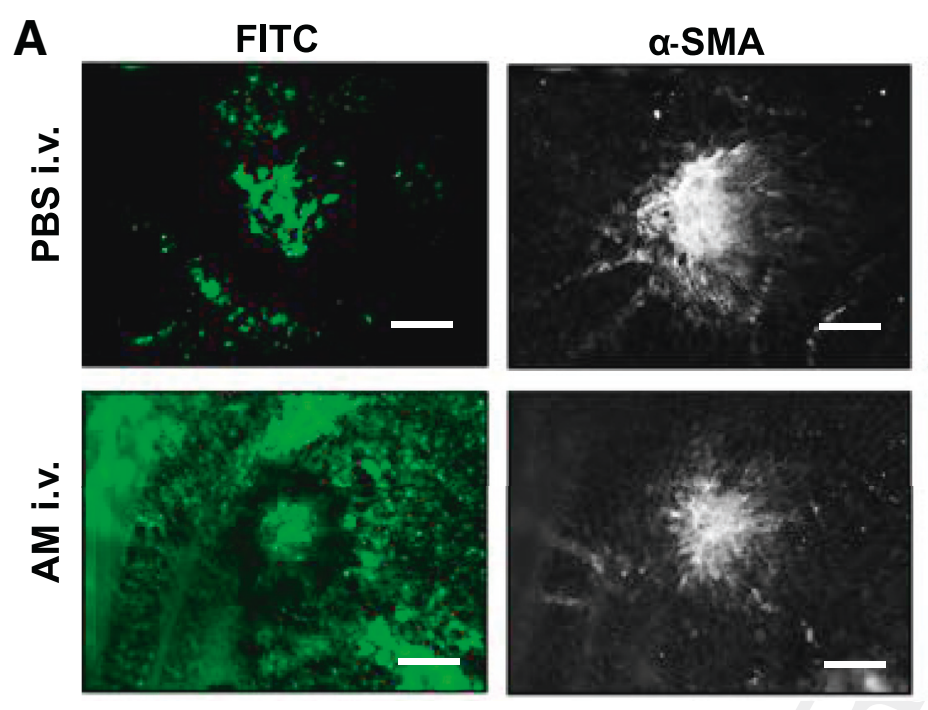

B
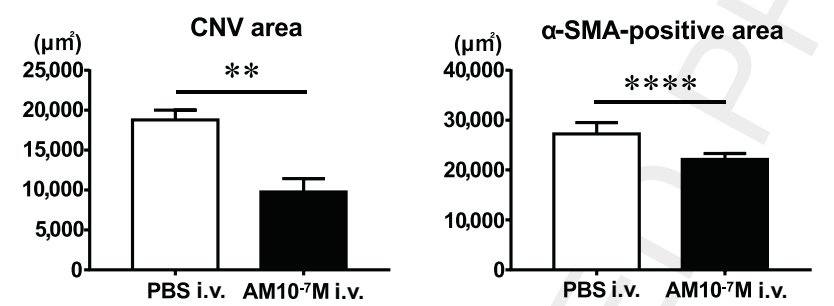

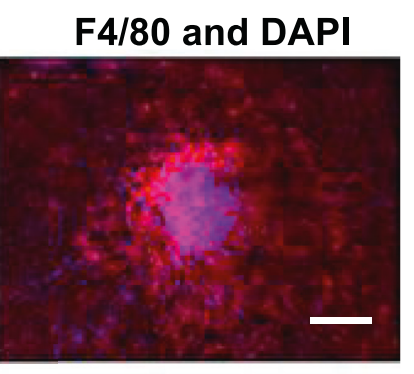

Figure 3 Choroidal flat mount analysis of laser-induced choroidal neovascularization (LI-CNV), fibrosis, and macrophage invasion in adrenomedullin (AM)-administered mice. A: Comparison of LI-CNV in the laser injury model between AM-administered and control mice. After the laser irradiation, mice were injected once into the posterior vitreous with phosphate-buffered saline (PBS; $1 \mu \mathrm{mol} / \mathrm{L} ; 1 \mu \mathrm{L} ;$ control) or AM ( $\left.10^{-7} \mathrm{~mol} / \mathrm{L} ; 1 \mu \mathrm{L}\right)$. On day 7 after the laserinduced injury, choroidal flat mounts were prepared, the fluorescein isothiocyanate (FITC)-positive CNV and $\alpha$-smooth muscle actin ( $\alpha$-SMA)-immunopositive fibrotic areas were measured, and the number of F4/80-immunopositive macrophages were counted. B: Bar graphs comparing the CNV and fibrotic areas and macrophage invasion between control and AM-administered mice. Data are given as means $\pm \operatorname{SEM}(\mathbf{B}) . n=10$ in each group (B). ${ }^{* * P}<0.01,{ }^{* * * * P}<0.0001$ (t-test). Scale bars $=100 \mu \mathrm{m}(\mathbf{A})$.

ophthalmoscope, was performed, according to a previous study, ${ }^{28}$ to confirm that there was no apparent choroidal and retinal vascular change in AM KO, RAMP2 KO, and RAMP3 KO under baseline conditions (Supplemental Figure S1). While keeping the cornea moist with saline, mice were manually held in front of a Heidelberg Retina Angiograph 2 confocal scanning-laser ophthalmoscope (Heidelberg Engineering GmbH, Heidelberg, Germany). Indocyanine green angiography was performed after tail vein injection of $2 \mathrm{mg} / \mathrm{kg}$ indocyanine green (Santen Pharmaceutical, Osaka, Japan). Images were taken at 10 minutes after injection.

\section{Continuous Administration of AM to Mice}

Male C57BL/6J mice, aged 9 to 12 weeks (Charles River Laboratories Japan, Kanagawa, Japan), were used. Human AM (Peptide Institute, Inc., Osaka, Japan) dissolved in phosphate-buffered saline (PBS) was infused subcutaneously using an osmotic pump (Alzet; DURECT Co, Cupertino, CA). The infusion rate was $29 \mu \mathrm{g} / \mathrm{kg}$ per day, and the infusion duration was 7 or 14 days. PBS was used as a control. The effectiveness of human AM in mice is well established, ${ }^{29,30}$ and the dosage used was selected on the basis of earlier studies. ${ }^{17,18}$

\section{Intravitreal Administration of AM to Mice}

Human AM $\left(10^{-7} \mathrm{~mol} / \mathrm{L} ; 1.0 \mu \mathrm{L}\right)$ in PBS was injected intravitreally into anesthetized mice under a surgical microscope at the corneal scleral junction using a Hamilton syringe equipped with a 32-gauge needle. PBS $(1.0 \mu \mathrm{L})$ was used as a control. After operative procedures, mice were administered moxifloxacin hydrochloride (Vegamox Ophthalmic Solution; Alcon, Fudenberg, Switzerland).

\section{LI-CNV Model}

After anesthesia, both eyes were dilated with $0.5 \%$ tropicamide and $0.5 \%$ phenylephrine (Mydrine P; Santen, Osaka, Japan). Laser injury to the retina was performed using a green laser slit lamp (GYC-1000; NIDEK, Gamagori, Japan). At that time, a cover glass and a viscoelastic substance were used as contact lenses. The wavelength was 532 $\mu \mathrm{m}$, the power output was $200 \mathrm{~mW}$, lasing duration was 0.05 seconds, the spot size was $50 \mu \mathrm{m}$, and the laser injuries were generated in an area where there were no obvious 


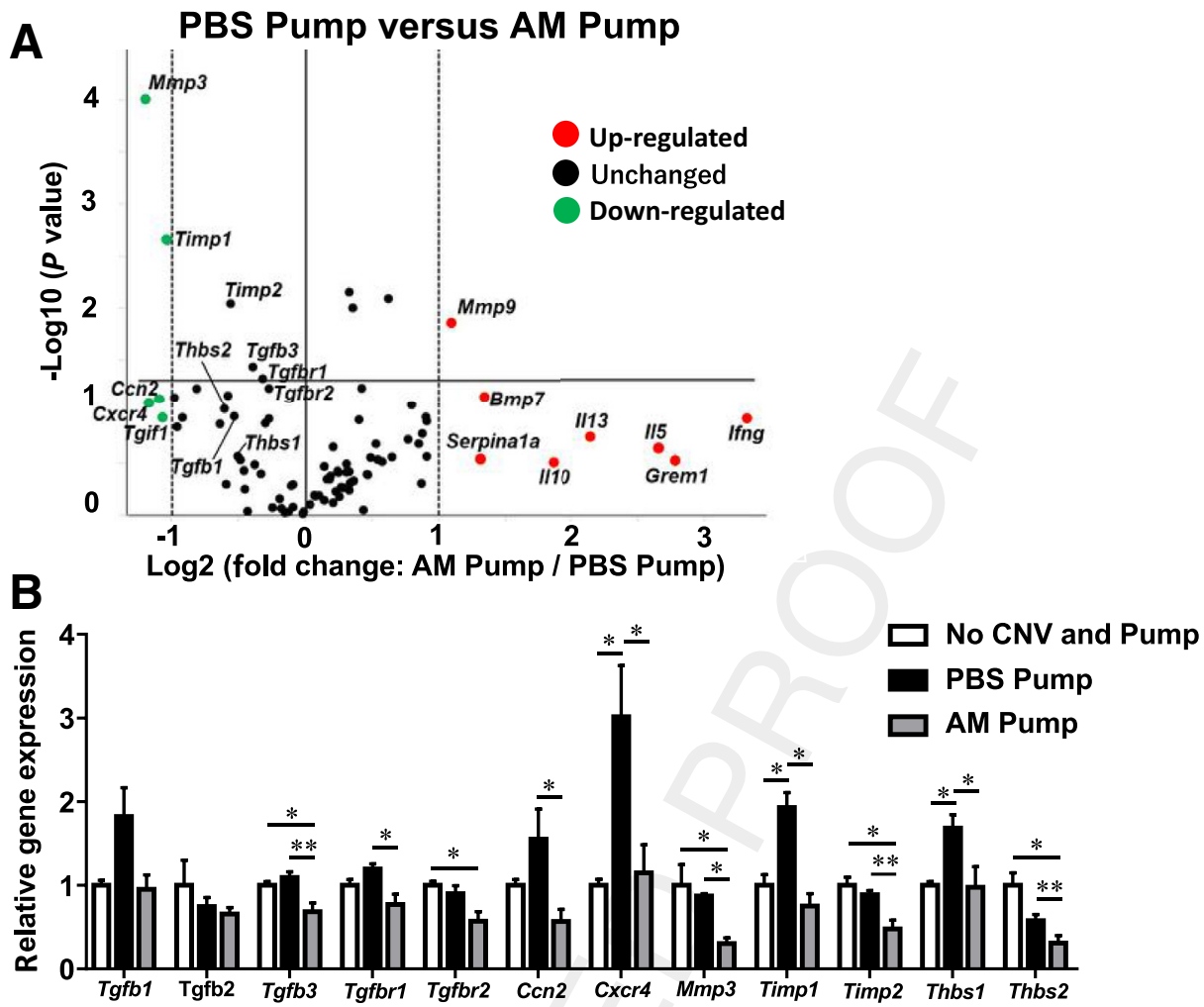

Figure 4 Comprehensive gene expression analysis in the choroids after laser irradiation with or without adrenomedullin (AM) administration. A: Following laser irradiation, AM or phosphate-buffered saline (PBS) was administered using subcutaneously implanted osmotic pumps. On day 14, choroids were collected for comprehensive gene expression analysis of mouse fibrosis-related factors. The dot plot shows the results of the real-time PCR array analysis. The horizontal axis shows the fold change [ $\log _{2}$ (fold change)], and the vertical axis shows the $P$ value $\left[-\log _{10}(P\right.$ value) $]$. Dashed lines indicate the distribution of unchanged genes. B: Quantitative real-time PCR analysis of the expression of fibrosis-related genes in the choroids after 14 days of laser irradiation with administration of PBS or AM. The mean of the untreated group (without laser irradiation) was assigned a value of 1. Data are expressed as means \pm SEM (B). $n=4$ in each group (B). ${ }^{*} P<0.05,{ }^{*} P<0.01$ (one-way analysis of variance with the Tukey test). CNV, choroidal neovascularization.

retinal vessels around the optic nerve. Injury to the Bruch membrane was confirmed by the appearance of air bubbles. Three shots per eye were used to evaluate the sizes of the $\mathrm{CNV}$ and fibrotic area, and five shots were used before extracting mRNA from the choroid. After treatment, $3.0 \mathrm{mg} /$ $\mathrm{kg}$ of atipamezole (ZEOAQ, Fukushima, Japan) was intraperitoneally injected to reverse the anesthesia.

In the LI-CNV experiment using mice, the procedure for intravitreal injection, itself, affects the degree of $\mathrm{CNV}$ formation. Therefore, in the studies of intravitreal injection, we evaluated the effects only in comparison with control of each experiment. As LI-CNV lesions appeared to be decreased toward 3 weeks, we analyzed samples from 1 to 2 weeks.

\section{FITC Dextran Perfusion and Retinal Flat Mount}

Seven days after LI-CNV induction, mice were anesthetized, a thoracotomy was performed, and $1 \mathrm{~mL}$ of PBS containing 50 $\mathrm{mg} / \mathrm{mL}$ fluorescein isothiocyanate (FITC)-labeled dextran (molecular weight, $2 \times 10^{6}$; Sigma-Aldrich, St. Louis, MO) was systemically administered from the left ventricle. The eyes were then enucleated and fixed with $4 \%$ paraformaldehyde for 1 hour, after which the cornea, lens, and retina were removed, and flat mounts of the scleral choroid complex were prepared. Eight pieces were cut radially from the rim toward the optic disc and mounted onto slide glass. FITC-positive areas represent CNV (patent vessels but not collapsed vessels). For immunostaining, after blocking with $1 \%$ bovine serum albumin, a rabbit anti-mouse $\alpha$-smooth muscle actin ( $\alpha$-SMA) antibody (Abcam, Cambridge, UK), rat anti-mouse F4/80 antibody (Bio-Rad, Hercules, CA), and rabbit anti-mouse ROCK1 antibody (Cell Signaling Tech- Q8 nology, Danvers, MA) were applied, followed by appropriate secondary antibodies. The flat mounts were then embedded in fluorescence mounting medium (Agilent Technologies, Santa Clara, CA) and inspected using a fluorescence microscope (BZ-9000; Keyence, Osaka, Japan). The sizes of the CNV, $\alpha$ SMA-positive, and ROCK-1-positive areas were quantified using an analytic application, BZ analyzer (Keyence). As we simply evaluated the areas and omitted the evaluation of the fluoresce intensity and thickness, the limitation is that we may underestimate the actual volume of the lesions. Numbers of F4/80-positive cells per CNV lesion were counted. Quantification was done using a double-blind method. In the flat Q9 mount analysis, $n$ represents the number of CNV lesions. 

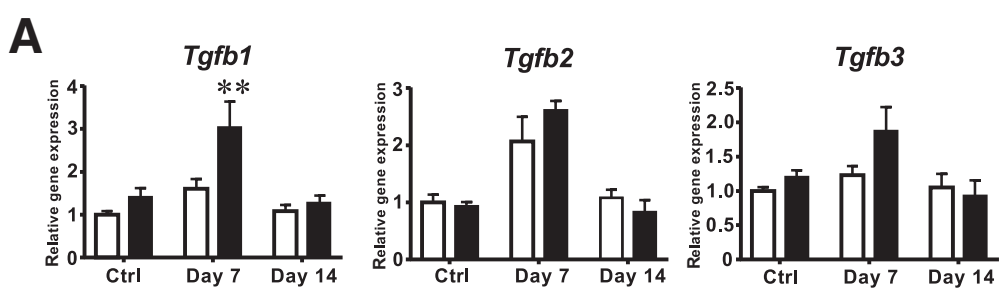

Cxcr4
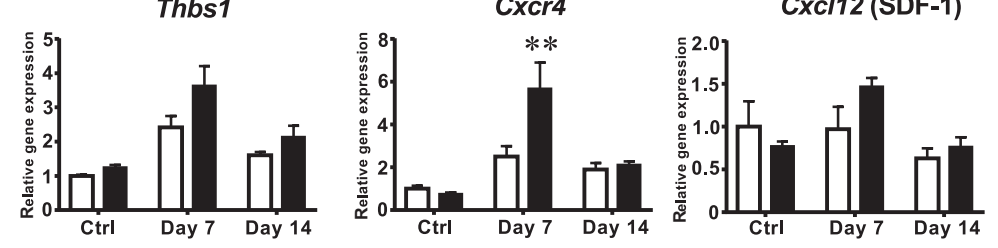

Cxcl12 (SDF-1)
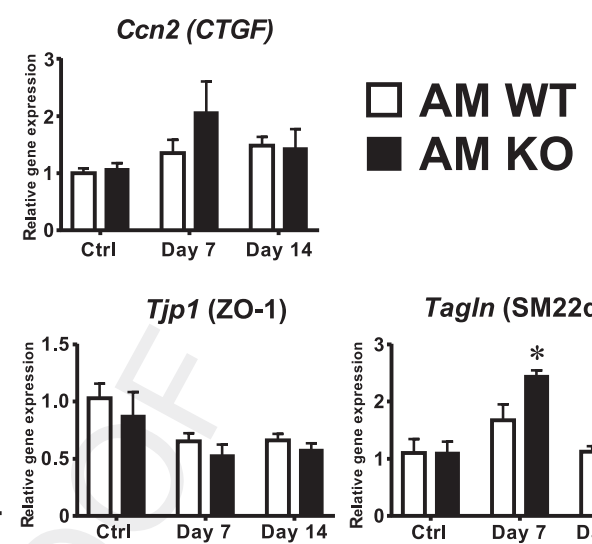

$\operatorname{Tag} \ln (\mathrm{SM} 22 \alpha)$

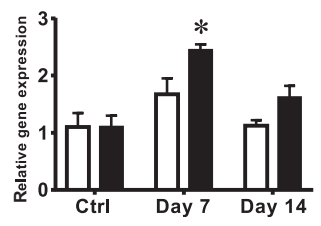

B
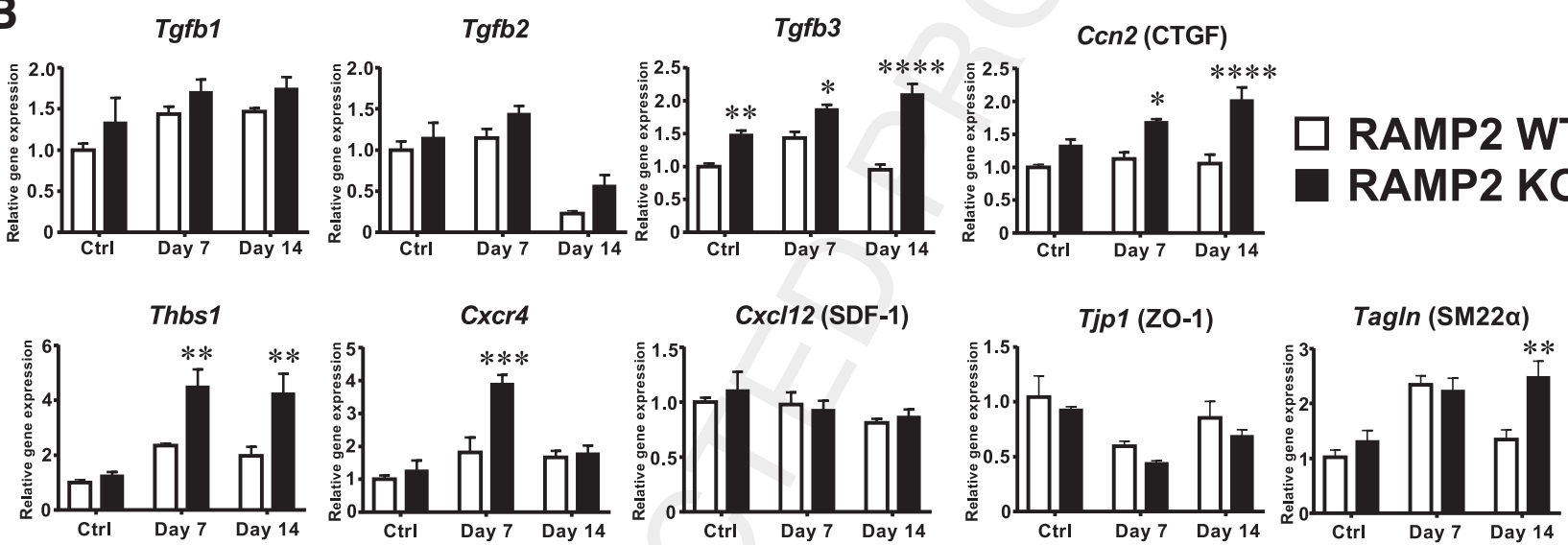

Figure 5 Up-regulation of fibrosis-related genes in the choroids of adrenomedullin (AM) knockout (K0) and RAMP2 K0 mice after laser irradiation. A: Quantitative real-time PCR analysis of the expression of fibrosis-related genes. Gene expression was compared between choroids from wild-type (WT) and AM KO mice untreated (Ctrl) and on days 7 and 14 after laser irradiation. The mean of the untreated WT mice was assigned a value of 1. B: Quantitative real-time PCR analysis of the expression of fibrosis-related genes. Gene expression was compared between choroids from WT and RAMP2 K0 untreated (Ctrl) and on days 7 and 14 after laser irradiation. Data are expressed as means \pm SEM (A and $\mathbf{B}) . n=4$ in each group $(\mathbf{A}$ and $\mathbf{B}) .{ }^{*} P<0.05,{ }^{* *} P<0.01, * * * P<0.01$, and $* * * * P<0.001$ versus AM WT (two-way analysis of variance with the Tukey test). CTGF, connective tissue growth factor; SDF-1, stromal cell-derived factor-1; Q17 Z0-1, zonula occludens protein 1.

\section{Pathologic Sections}

Seven days after laser irradiation, the eyes were enucleated, fixed in $4 \%$ paraformaldehyde overnight, and embedded in paraffin, after which sections ( $5 \mu \mathrm{m}$ thick) were prepared for histologic analysis. Sections were stained with hematoxylin/ eosin and Masson trichrome stain and immunostained using anti- $\alpha$-SMA (Agilent Technologies, Santa Clara, CA), antiAM (Thermo Fisher Scientific, Waltham, MA), and anti-CLR (Abcam) antibodies with diaminobenzidine and fluorescent anti-RhoA antibody (Abcam).

\section{Quantitative Real-Time RT-PCR}

Mice were sacrificed, and their eyes were enucleated. The cornea, iris, lens, vitreous, and surrounding soft tissues were removed. Finally, the retina was peeled off by pushing the RPE-choroid-sclera complex (choroidal complex) from behind. Total RNA was extracted from choroidal complexes or ARPE19 cells using TRIzol Reagent (Thermo Fisher Scientific). The extracted RNA was then treated with DNAfree (Thermo Fisher Scientific) to remove any contaminating DNA, and a 2- $\mu \mathrm{g}$ sample was reverse transcribed using a PrimeScript RT Reagent Kit (Takara Bio, Shiga, Japan) to produce cDNA. Quantitative real-time RT-PCR was performed using a StepOnePlus real-time PCR system (Thermo Fisher Scientific), SYBR Green (Toyobo, Osaka, Japan), and real-time PCR master mix (Toyobo). Glyceraldehyde-3-phosphate dehydrogenase (Thermo Fisher Scientific) expression was in the endogenous control. Table 1 shows the primers used. In the gene expression analysis of the choroidal complexes, $n$ represents the number of mice.

\section{Real-Time RT-PCR Array Assay Analysis}

Genes in the mouse choroid were comprehensively evaluated using a PCR array assay ( $\mathrm{RT}^{2}$ Profiler PCR Array; Qiagen, Hilden, Germany). After converting $1 \mu \mathrm{g}$ of total 


\section{A}
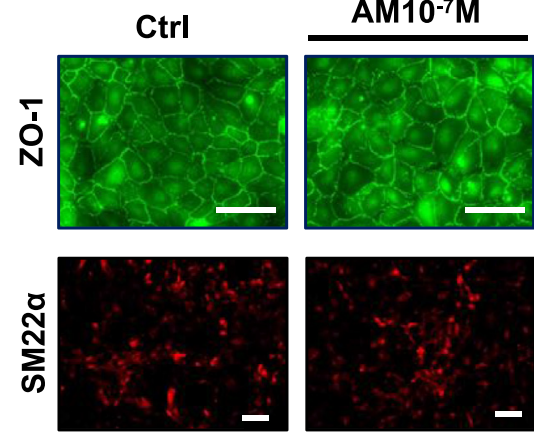

B
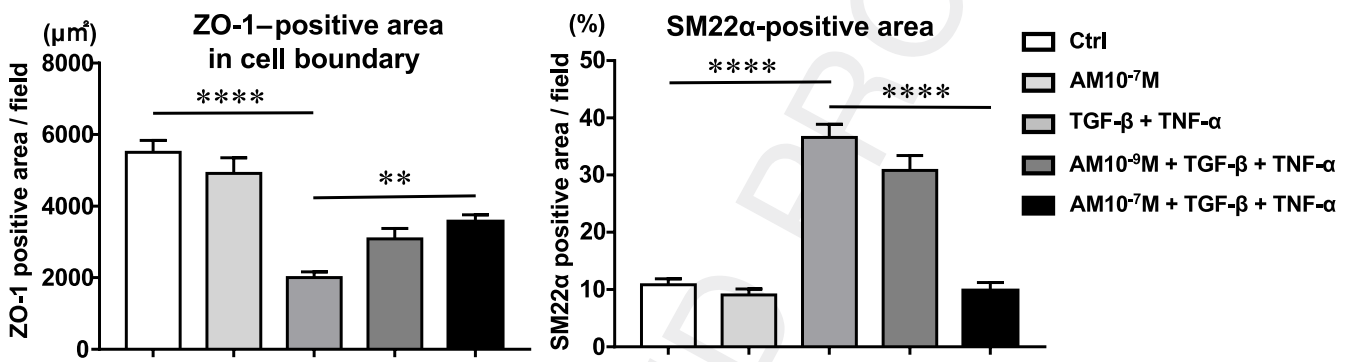

Figure 6 Suppression of epithelial-mesenchymal transition (EMT) in cultured retinal pigment epithelial cells by adrenomedullin (AM). A: Immunostaining for zonula occludens protein 1 (ZO-1; top row) and SM22 $\alpha$ (bottom row) in ARPE19 human retinal pigment epithelial cells. Cells were stimulated with transforming growth factor- $\beta$ (TGF- $\beta ; 5 \mathrm{ng} / \mathrm{mL}$ ) plus tumor necrosis factor- $\alpha(\mathrm{TNF}-\alpha ; 10 \mathrm{ng} / \mathrm{mL})$ for 48 hours to induce EMT. AM $\left(10^{-9}\right.$ or $\left.10^{-7} \mathrm{~mol} / \mathrm{L}\right)$ was added 24 hours before EMT induction. Z0-1 and SM22 $\alpha$ were used as epithelial and mesenchymal markers, respectively. B: Bar graphs showing the Z0-1- and SM22 $\alpha$-positive areas/field. For Z0-1, only the cell boundary region was measured. Data are expressed as means \pm SEM (B). $n=6$ in the AM group (B); $n=10$ in the other groups $(\mathbf{B}) .{ }^{* *} P<0.01,{ }^{* * *} P<0.0001$ (one-way analysis of variance with the Tukey test). Scale bars $=100 \mu \mathrm{m}(\mathbf{A}) .0$ riginal magnification, $\times 200$ (A, top row); $\times 100$ (A, bottom row). Ctrl, control.

choroidal complex RNA into cDNA using a $\mathrm{RT}^{2}$ First Strand Kit (Qiagen), a PCR array of fibrosis-related factors was performed according to the manufacturer's protocol. All PCRs were performed using the StepOnePlus real-time PCR system. $\mathrm{RT}^{2}$ profiler PCR array data were analyzed using $\mathrm{RT}^{2}$ profiler array data analysis software version 3.5 (Thermo Fisher Scientific).

\section{Western Blot Analysis}

Western blot analysis was performed using protein extract from choroidal complex. The lysates were subjected to electrophoresis in TGX gel (Bio-Rad Laboratories), transferred to polyvinylidene difluoride membranes (Bio-Rad Laboratories), and probed using anti-Smad2, anti-Smad3, anti-phosphorylated Smad2, anti-phosphorylated Smad3 (Cell Signaling Technology), and anti-AM (Thermo Fisher Scientific) antibodies. Anti- $\beta$-actin antibody (Abcam) served as a loading control. The blots were developed using an ImageQuant LAS 4000 (GE Healthcare, Chicago, IL). In the Western blot analysis of the choroidal complexes, $n$ represents the number of mice.

\section{Inhibitor Administration}

After laser irradiation, SB431542 (Cayman Chemical, Ann Arbor, MI), a transforming growth factor- $\beta$ (TGF- $\beta$ ) inhibitor, was intraperitoneally injected daily at $10 \mathrm{mg} / \mathrm{kg}$ in $5 \%$ dimethyl sulfoxide, as described previously. ${ }^{31}$ Dimethyl sulfoxide at 5\% served as the control. Plerixafor (SigmaAldrich), a CXCR4 inhibitor, was injected once into the posterior vitreous cavity $(200 \mathrm{mmol} / \mathrm{L} ; 1 \mu \mathrm{L})$, as described previously. ${ }^{32}$ PBS served as the control. Y27632 (Enzo Life Science, Inc., Farmingdale, NY), a ROCK inhibitor, was injected into the vitreous body $(30 \mu \mathrm{mol} / \mathrm{L} ; 1 \mu \mathrm{L})$ every 3 days, as described previously. ${ }^{33}$ PBS served as the control.

\section{Human RPE Cells}

ARPE19 immortalized human RPE cells were purchased from ATCC (Manassas, VA). The cells were cultured in medium supplemented with $10 \%$ fetal bovine serum and penicillin/streptomycin at $37^{\circ} \mathrm{C}$ and under $5 \% \mathrm{CO}_{2}$.

TGF- $\beta 2(5 \mathrm{ng} / \mathrm{mL})$ and tumor necrosis factor- $\alpha$ (TNF- $\alpha$; $10 \mathrm{ng} / \mathrm{mL}$ ) were added before the cells became confluent. When AM $\left(10^{-7}\right.$ or $\left.10^{-9} \mathrm{~mol} / \mathrm{L}\right)$ was used, it was added 24 hours before the addition of TGF- $\beta 2$ plus TNF- $\alpha$. The 


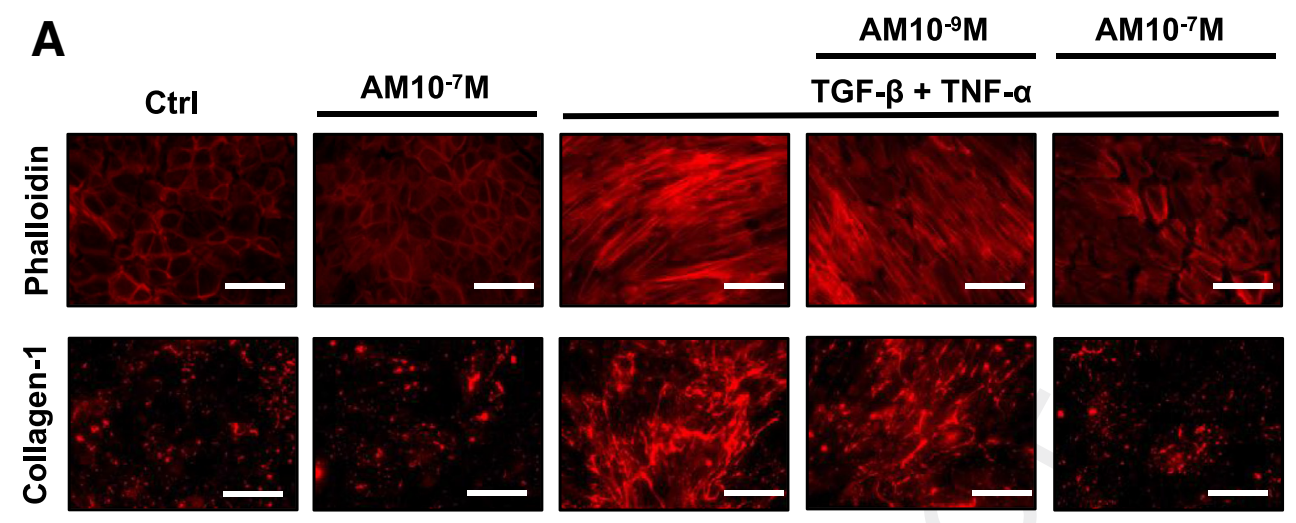

\section{B}
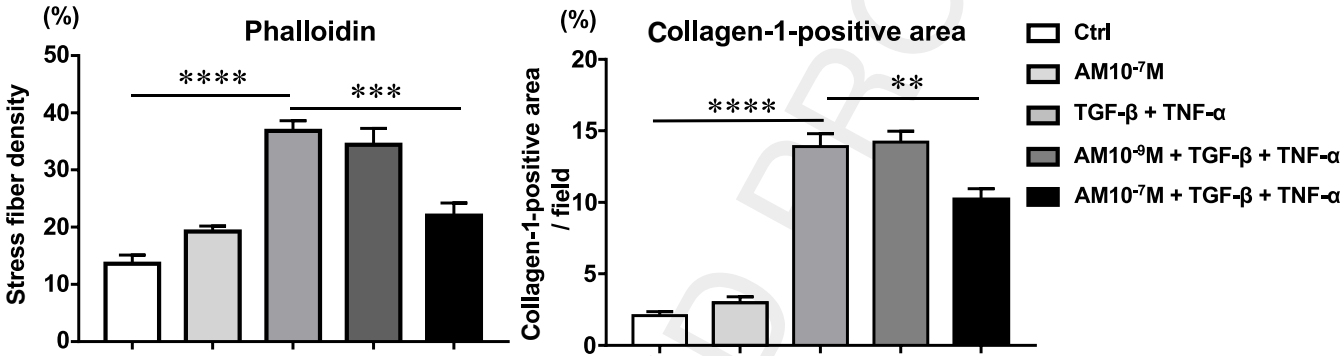

Figure 7 Changes of actin filaments and collagen in cultured retinal pigment epithelial cells after epithelial-mesenchymal transition (EMT) induction. A: ARPE19 cells were stained with phalloidin (top row) or immunostained for collagen-1 (bottom row) to evaluate the changes in the actin cytoskeleton and extracellular matrix induced by EMT, which was elicited by incubation with transforming growth factor- $\beta$ (TGF- $\beta ; 5 \mathrm{ng} / \mathrm{mL}$ ) plus tumor necrosis factor- $\alpha$ (TNF- $\alpha$; $10 \mathrm{ng} / \mathrm{mL}$ ) for 48 hours. Adrenomedullin (AM; $10^{-9}$ or $10^{-7} \mathrm{~mol} / \mathrm{L}$ ) or phosphate-buffered saline was added 24 hours before EMT induction. B: Bar graphs showing the percentage of phalloidin-positive actin filament area/cell and collagen-1 immunostaining-positive area/field. Data are expressed as means \pm SEM (B). $n=10$ in each group (B). ${ }^{* *} P<0.01,{ }^{* *} P<0.001$, and ${ }^{* * * * P}<0.0001$ (one-way analysis of variance with the Tukey test). Scale bars $=100 \mu \mathrm{m}(\mathbf{A})$. Original magnification, $\times 200($ A). Ctrl, control.

dosage and treatment period were chosen on the basis of previous studies. ${ }^{34-36}$

Thereafter, the plate was dipped in $4 \%$ paraformaldehyde for 10 minutes, blocked, and immunostained with anti-zonula occludens protein 1 (ZO-1; 1:200 dilution; BD Q11 Biosciences, Franklin Lakes, NJ), anti-SM22 $\alpha$ (1:200 dilution; Abcam), and anti-collagen $\alpha 1$ (1:200 dilution; Novus Biologicals, Littleton, CO) antibodies. Cells were also stained with phalloidin (Thermo Fisher Scientific) to visualize actin fibers. Cells were then examined under a microscope (BZ9000). Positive areas were determined using Hybrid Cell Count (BZ analyzer) under the same conditions. Phalloidinpositive intracellular fiber concentrations were determined, as described previously. ${ }^{37}$ Phalloidin-stained cells were randomly selected, and their images were enlarged for binarization using ImageJ software version $1.53 \mathrm{f}(\mathrm{NIH}$, Bethesda, MD; http://imagej.nih.gov/ij). Fluorescence density was measured along a line perpendicular to the stress fibers at the longest intracellular distance. The obtained average values served as the fiber density.

\section{Statistical Analysis}

Statistical analysis was performed using GraphPad Prism 7.00 (GraphPad Software Inc., La Jolla, CA). Values are expressed as the means \pm SEM, and the significance of differences was assessed using $t$-test, one-way analysis of variance with the Tukey test, or two-way analysis of variance with the Tukey test. $P<0.05$ was considered significant.

\section{Results}

\section{Pathology of LI-CNV and Expression of AM and Its} Related Genes

First analyzed were the pathologic changes in the retina after laser injury in C57BL/6J WT mice. LI-CNV was confirmed under the retina (Figure 1A) in the sections prepared 7 days after laser irradiation. Consistent with LI-CNV formation, immunostaining for $\alpha$-SMA, a marker of activated myofibroblasts, was positive, as was Masson trichrome staining. Although Masson trichrome also stained extracellular matrix in retinal areas outside the LI-CNV lesion, the immunostaining for $\alpha$-SMA was largely limited to the lesion and is thought to more selectively reflect the progression of fibrosis. Thereafter, subretinal fibrosis was evaluated on the basis of $\alpha$-SMA immunostaining.

To clarify the involvement of the AM-RAMP2 system, we analyzed the expression of AM and its receptor components (Figure 1B). Following the laser irradiation, 

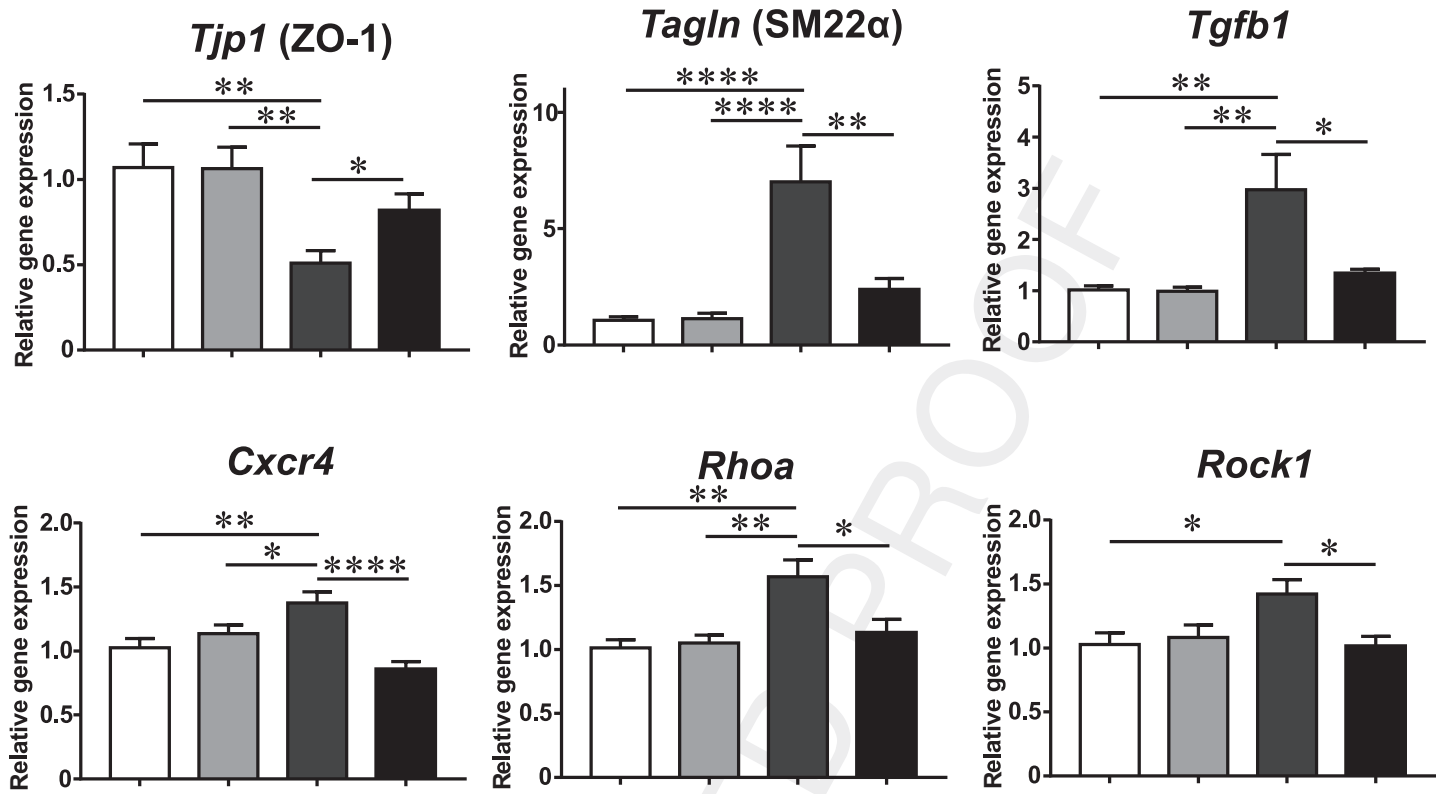

Figure 8 Changes in gene expression in cultured retinal pigment epithelial cells after induction of epithelial-mesenchymal transition (EMT). Quantitative real-time PCR analysis of gene expression in ARPE19 cells. Cells were stimulated with transforming growth factor- $\beta$ (TGF- $\beta ; 5 \mathrm{ng} / \mathrm{mL}$ ) plus tumor necrosis factor- $\alpha$ (TNF- $\alpha ; 10 \mathrm{ng} / \mathrm{mL}$ ) for 48 hours to induce EMT. Adrenomedullin (AM; $10^{-7} \mathrm{~mol} / \mathrm{L}$ ) or phosphate-buffered saline was added 24 hours before EMT induction. The mean of the control (Ctrl) group was assigned a value of 1. Data are expressed as means \pm SEM. $n=12$ in CXCr4 and Tjp $1 ; n=8$ in others. ${ }^{*} P<0.05,{ }^{* *} P<0.01$, and ${ }^{* * *} P<0.0001$ (one-way analysis of variance with the Tukey test). Z0-1, zonula occludens protein 1 .

expression levels of AM, RAMP2, and RAMP3 reached their peaks on day 1 , and then gradually returned to basal levels by day 7 . On the other hand, CLR expression gradually increased from day 1 to day 7 . The significant upregulation of $\mathrm{AM}$ and its receptor components strongly suggests involvement of AM in the pathogenesis of LICNV. AM and CLR protein expression within LI-CNV lesions was also analyzed by immunohistostaining and Western blot analysis (Supplemental Figure S2).

\section{Evaluation of Flat Mount LI-CNV Specimens from AM, RAMP2, or RAMP3 K0}

Next, using AM KO and RAMP2 KO mice and their WT littermates, the pathophysiological functions of the endogenous AM-RAMP2 system were evaluated. Seven days after laser irradiation, FITC-dextran was systemically administered via the left ventricle. Thereafter, eyes were collected, and choroidal flat mounts prepared. We evaluated FITCpositive vascular area as the size of the CNV. We then immunostained for $\alpha$-SMA, to evaluate the degree of subretinal fibrosis, and for F4/80, a macrophage marker, to evaluate the degree of inflammatory cell infiltration. FITC imaging revealed the average size of the $\mathrm{CNV}$ to be significantly larger in AM KO than WT mice $(15,508$ 2] $\mu \mathrm{m}^{2}$ versus $8309 \mu^{2}$ ) (Figure 2, A and B). The
$\alpha$-SMA-positive fibrotic area was also significantly larger in AM KO mice $\left(23,023 \mu \mathrm{m}^{2}\right.$ versus $\left.10,638 \mu \mathrm{m}^{2}\right)$. Moreover, the difference after subtraction of the CNV area from the $\alpha$-SMA-positive area, which reveals the fibrosis spreading beyond the $\mathrm{CNV}$, was significantly larger in $\mathrm{AM}$ KO than WT mice $\left(7515 \mu \mathrm{m}^{2}\right.$ versus $\left.2328 \mu \mathrm{m}^{2}\right)$.

The number of infiltrating F4/80-positive macrophages was also significantly higher in AM KO mice (52 versus 29). Similarly, comparison of WT and RAMP2 KO mice showed that the average $\mathrm{CNV}$ was significantly larger in RAMP2 KO than WT mice $\left(18,070 \mu \mathrm{m}^{2}\right.$ versus $\left.6655 \mu \mathrm{m}^{2}\right)$, as was fibrotic area $\left(26,462 \mu \mathrm{m}^{2}\right.$ versus $\left.9678 \mu \mathrm{m}^{2}\right)$ and the number of infiltrating F4/80-positive macrophages (55 versus 34 ) (Figure 2, $\mathrm{C}$ and $\mathrm{D})$. These observations indicate that the endogenous AM-RAMP2 system works to suppress CNV formation, fibrosis, and inflammation after laser injury. On the other hand, ratio of $\alpha$-SMA-positive area/CNV area was not different in both AM KO and RAMP2 KO compared with WT mice, which may indicate that larger $\mathrm{CNV}$ accompanies with lager fibrosis (Supplemental Figure S3).

The involvement of RAMP3 after laser injury was also evaluated. Unlike AM and RAMP2 KO, RAMP3 KO did not significantly affect CNV size, degree of fibrosis, or inflammation (Supplemental Figure S4). Thus, the AM-RAMP2 system, but not the AM-RAMP3 system, works to suppress the pathologic changes associated with laser injury. 

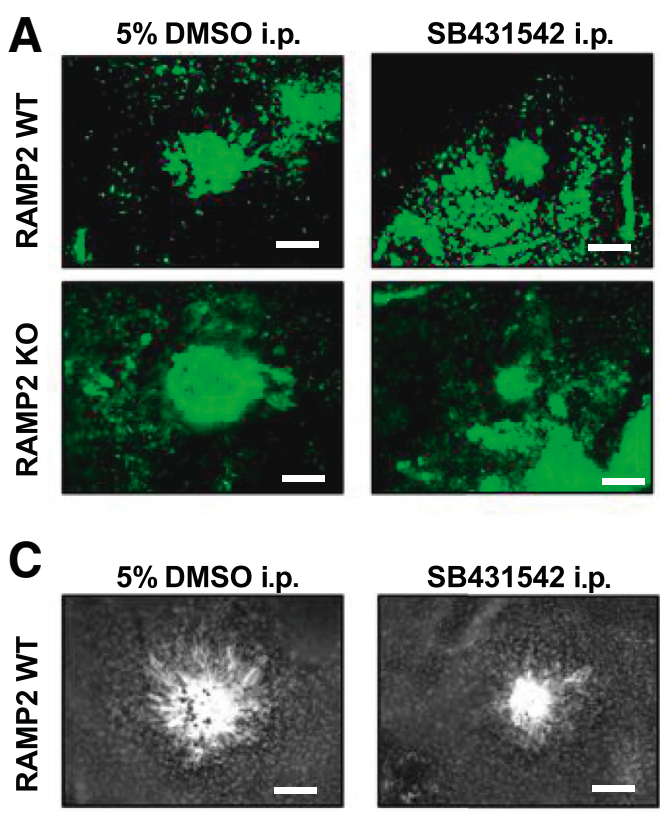

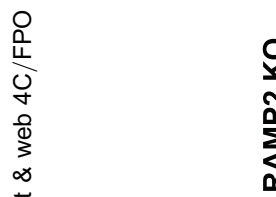
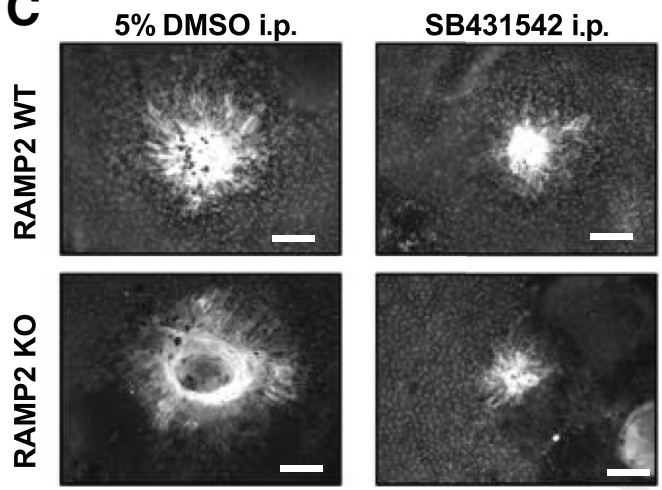

Figure 9 Transforming growth factor- $\beta$ (TGF- $\beta$ ) inhibition eliminates the enhanced subretinal fibrosis in RAMP2 knockout (K0) mice. Experiments with SB431542 (TGF- $\beta$ inhibitor). Mice were peritoneally injected SB431542 or 5\% dimethyl sulfoxide (DMS0; control) every day after the laser irradiation. Flat mounts were prepared 7 days after laser injury. A: Fluorescein isothiocyanate-positive choroidal neovascularization (CNV). B: Comparison of CNV area between RAMP2 K0 and wild type (WT) with or without the inhibitor. C: $\alpha$-Smooth muscle actin ( $\alpha$-SMA)-immunopositive fibrotic area. D: Comparison of $\alpha$-SMA-positive fibrotic area between RAMP2 K0 and WT with or without the inhibitor. Data are expressed as means \pm SEM (B and D). $n=7$ to 9 in each group (B and D). ${ }^{* *} P<0.01,{ }^{* * *} P<0.001$ versus RAMP2 WT (two-way analysis of variance with the Tukey test). Scale bars $=100 \mu \mathrm{m}(\mathbf{A}$ and $\mathbf{C})$.

Effect of the Intravitreal Injection of AM in Flat Mount Specimens of LI-CNV

Given that the endogenous AM-RAMP2 system appears to act to suppress the pathologic changes associated with LI$\mathrm{CNV}$, we next assessed the effect of exogenous adminis-

[F3] tration of AM (Figure 3). After laser irradiation of C57BL/ $6 \mathrm{~J}$ WT mice, control PBS or AM was administered intraocularly. Because intraocular injection itself causes damage and results in the enlargement of the LI-CNV in mice, ${ }^{19}$ we compared the effects of AM injection with control PBS injection. The size of the CNV in mice administered PBS was significantly larger than in those administered AM $\left(18,779 \mu \mathrm{m}^{2}\right.$ versus $\left.9770 \mu \mathrm{m}^{2}\right)$. Likewise, the size of the $\alpha$ SMA-positive fibrotic area was significantly larger in the control than AM group $\left(27,265 \mu \mathrm{m}^{2}\right.$ versus $\left.22,185 \mu \mathrm{m}^{2}\right)$. And although there was an average of 65 F4/80-positive macrophages inside or around each laser photocoagulation site in the control group, that was significantly reduced to 44 in the AM group.

These results indicate that, like the endogenous AMRAMP2 system, exogenous AM administration effectively suppresses the pathologic changes associated with LI-CNV.
Comprehensive Analysis of the Changes in Gene Expression in LI-CNV Induced by AM

To clarify the mechanism underlying the beneficial effect of $\mathrm{AM}$, we next performed a comprehensive gene expression analysis using an $\mathrm{RT}^{2}$ Profiler PCR Array of mouse fibrosisrelated factors. To overview the changes of fibrosis-related genes, PBS or AM was continuously administered to C57BL/6J WT mice using subcutaneously implanted osmotic pumps. Samples were then collected from the choroid 14 days after laser irradiation, and the gene expression profiles were analyzed. We found that the expression of fibrosis-related genes (Tgif1, Ccn2, Cxcr4, Mmp3, and Timp1) was down-regulated by AM administration (Figure 4A). Focusing on the fibrosis-related molecules, quantitative real-time PCR analysis confirmed that expression levels of genes encoding the TGF- $\beta$ family and its receptors, connective tissue growth factor, CXCR4, TIMP1, and thrombospondin 1 (Thbs1), were all significantly downregulated by AM administration (Figure 4B). Although Smads have been identified as the canonical downstream targets of TGF- $\beta$, no significant effect of AM administration on the expression of Smads was detected (Supplemental Figure S5). 

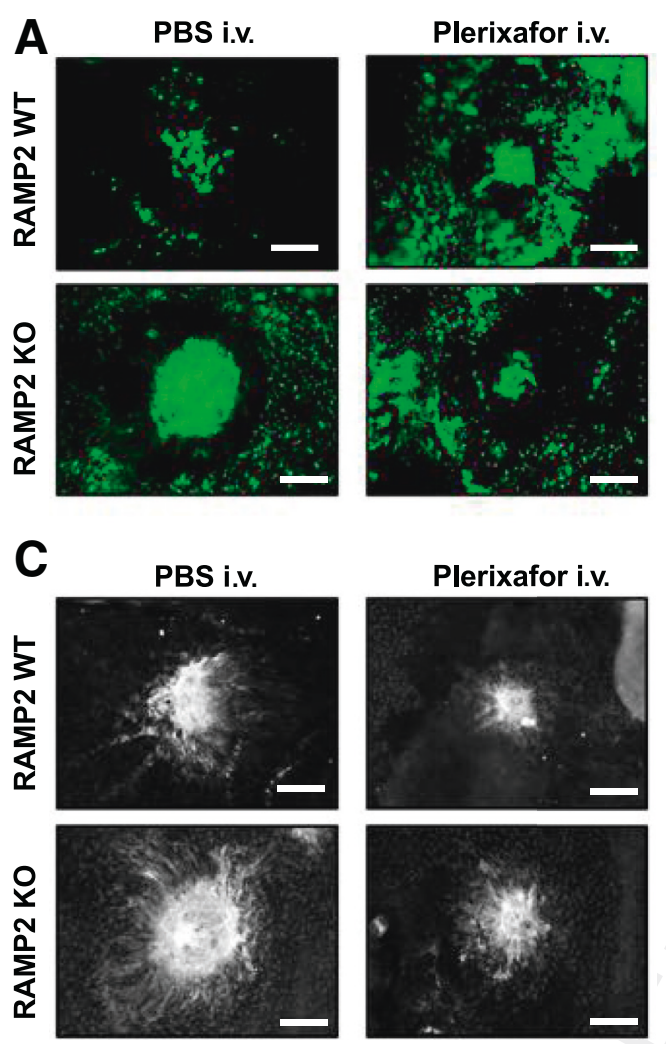

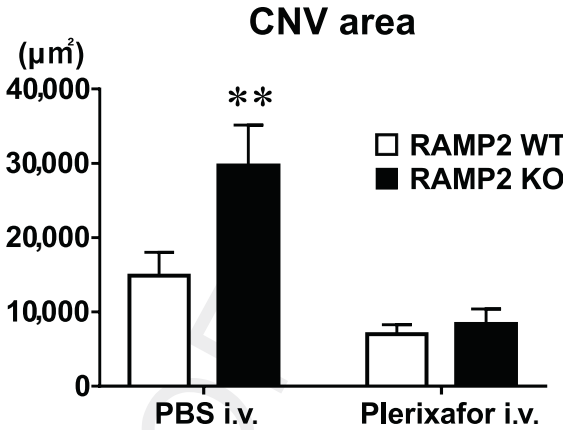

D

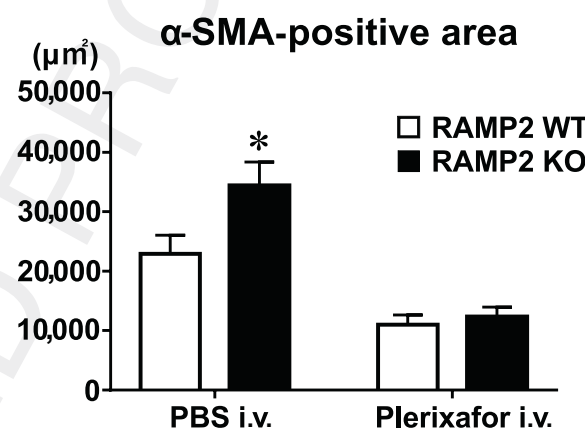




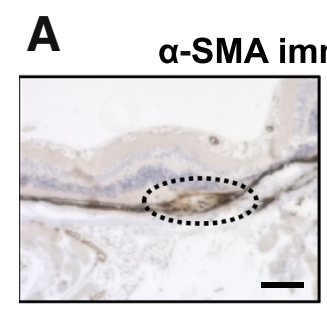

RAMP2 WT

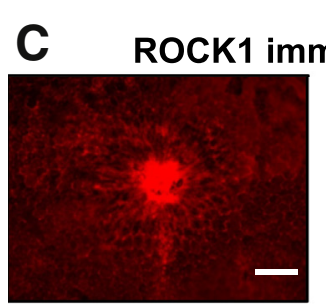

RAMP2 WT

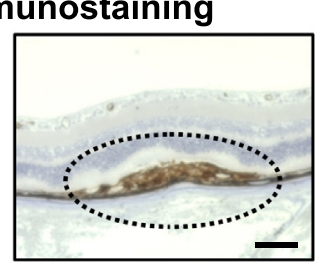

RAMP2 KO

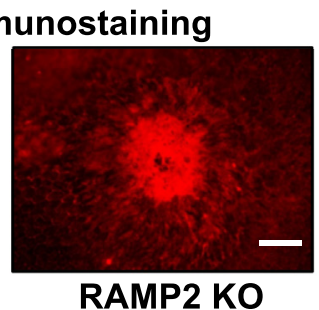

E
B

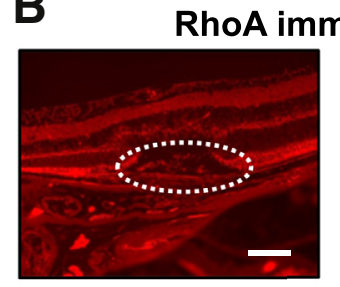

RAMP2 WT

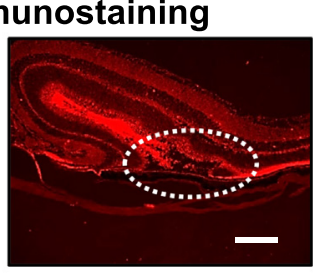

RAMP2 KO
D

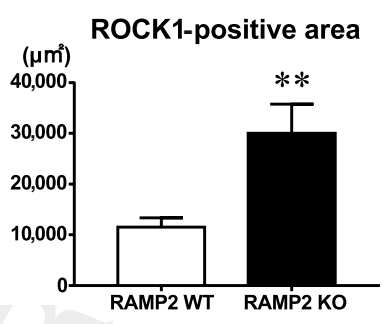

Rock1

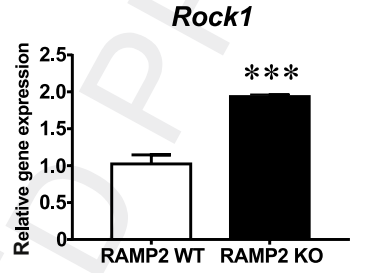
W: Comparison of the ROCK1-positive area between RAMP2 K0 and WT. E: Comparison of RhoA and Rock1 gene expression between RAMP2 KC $* * * P<0.001$ versus RAMP2 WT ( $t$-test). Scale bars $=100 \mu \mathrm{m}(\mathbf{A}-\mathbf{C})$.

For that reason, EMT was evaluated in ARPE19 cells, an immortalized human RPE cell line. To induce EMT, ARPE19 cells were stimulated for 48 hours with TGF- $\beta$ (5 $\mathrm{ng} / \mathrm{mL})$ plus TNF- $\alpha(10 \mathrm{ng} / \mathrm{mL})$. Immunostaining was performed to assess expression of ZO-1 (an epithelial cell marker detected in the cell membrane) and SM22 $\alpha$ (a [F6] cytosolic marker of mesenchymal cells) (Figure 6A). We found that stimulation with TGF- $\beta$ plus TNF- $\alpha$ resulted in down-regulation of ZO-1 and up-regulation of SM22 $\alpha$, which suggests induction of EMT (Figure 6B). Using this protocol, the cells were pretreated for 24 hours with or without AM $\left(10^{-9}\right.$ or $\left.10^{-7} \mathrm{~mol} / \mathrm{L}\right)$ before stimulation. AM $\left(10^{-7} \mathrm{~mol} / \mathrm{L}\right)$ significantly up-regulated $\mathrm{ZO}-1$ and downregulated SM22 $\alpha$, apparently preventing the effect of TGF- $\beta$ plus TNF- $\alpha$. In addition, phalloidin-positive actin filament formation (indicating myofibroblast-like changes in ARPE19 cells) and collagen-positive area (indicating accumulation of extracellular matrix) were both enhanced by TGF- $\beta$ plus TNF- $\alpha$ stimulation, which suggests EMT was actually induced. Those changes too were prevented by [F7] AM $\left(10^{-7} \mathrm{~mol} / \mathrm{L}\right)$ (Figure 7). This suppression of EMT may explain at least some of the protective effects of AM against subretinal fibrosis.

Gene expression analysis in this EMT model in ARPE19 cells also showed that stimulation with TGF- $\beta$ plus TNF- $\alpha$ resulted in down-regulation of genes encoding ZO-1 and upregulation of SM22 $\alpha$, and those effects were prevented by AM (Figure 8). The EMT stimulation also up-regulated expression of genes encoding TGF- $\beta$, CXCR4, RhoA, and ROCK, and those effects were prevented by AM.

\section{Effects of TGF- $\beta$, CXCR4, and ROCK Inhibitors on Subretinal Fibrosis}

We speculated that the protective effects of the AM-RAMP2 system against subretinal fibrosis in LI-CMV could be explained by suppression of fibrosis-related factors, such as TGF- $\beta$ and CXCR 4 , which is reportedly a downstream target of TGF- $\beta .^{40,41}$ To confirm the involvement of the TGF$\beta-$ CXCR4 pathway in subretinal fibrosis, we analyzed the effects of TGF- $\beta$ and CXCR4 inhibitors on LI-CNV and compared their effects in RAMP2 KO and WT mice.

We first evaluated the effect of i.p. injection of the TGF- $\beta$ inhibitor, SB431542. In the control 5\% dimethyl sulfoxide groups, CNV size was significantly larger in RAMP2 KO than WT mice $\left(23,797 \mu \mathrm{m}^{2}\right.$ versus 14,389 $\left.\mu \mathrm{m}^{2}\right)$ (Figure 9, A and B). By contrast, when SB431542 was administrated, there was no difference in CNV size between RAMP2 KO and WT mice $\left(8461 \mu \mathrm{m}^{2}\right.$ versus $8475 \mu \mathrm{m}^{2}$ ) (Figure 9, A and B). In the control groups, $\alpha$-SMA-positive fibrotic area was 

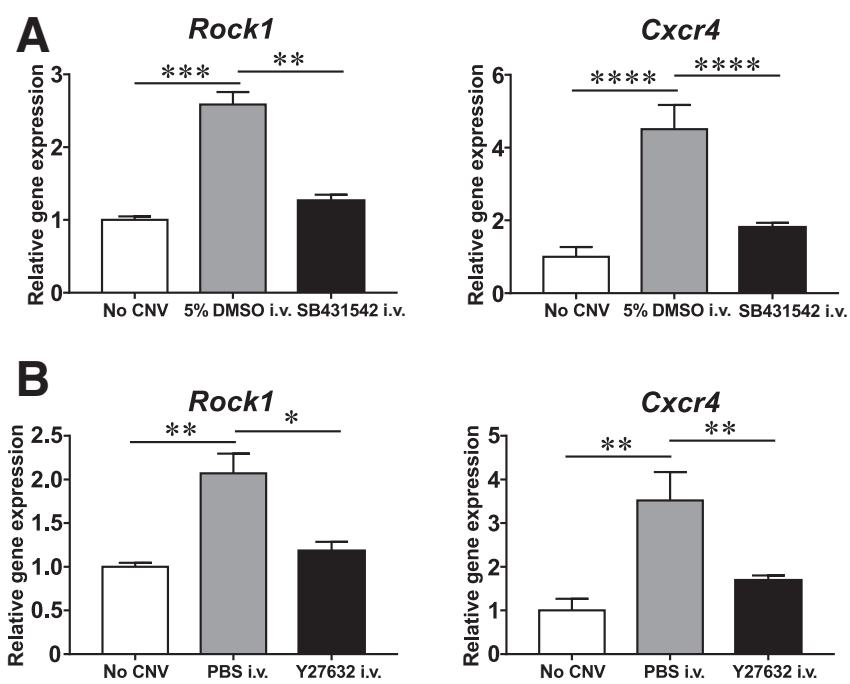

Figure 12 Down-regulation of $\mathrm{Cxcr} 4$ and Rock1 expression within laserinduced choroidal neovascularization (CNV) lesions by transforming growth factor- $\beta$ (TGF- $\beta$ ) or ROCK inhibitor. Following laser irradiation, wild-type (WT) mice were peritoneally injected with SB431542 (TGF- $\beta$ inhibitor) or $5 \%$ dimethyl sulfoxide (DMSO; control) daily (A), or they were intravitreally injected with Y27632 (ROCK inhibitor) or phosphate-buffered saline (PBS; control) every 3 days (B). Choroids were prepared 7 days after the laser irradiation, and quantitative real-time PCR analysis was performed. The mean of the untreated WT mice (no CNV) was assigned a value of 1. Data are expressed as means $\pm \operatorname{SEM}$ (A and $\mathbf{B}) . n=4$ in each group (A and $\mathbf{B}$ ). ${ }^{*} P<0.05,{ }^{* *} P<0.01,{ }^{* * *} P<0.001$, and ${ }^{* * * *} P<0.0001$ (one-way analysis of variance with the Tukey test).

also significantly larger in RAMP2 $\mathrm{KO}$ than WT mice $\left(26,711 \mu \mathrm{m}^{2}\right.$ versus $13,262 \mu \mathrm{m}^{2}$ ) (Figure 9, C and D). On the other hand, when SB431542 was administered, the fibrotic area was no larger in RAMP2 KO than in WT mice $\left(7750 \mu \mathrm{m}^{2}\right.$ versus $\left.8225 \mu \mathrm{m}^{2}\right)$. Similar results were obtained with intravitreal injection of the CXCR4 inhibitor, plerixafor

\section{F10] (Figure 10).}

We also speculated that TGF- $\beta$ and CXCR4 may interact with the RhoA-ROCK1 pathway, which is reportedly a downstream target of TGF- $\beta^{42}$ and involved in subretinal fibrosis. ${ }^{43}$ As described above, immunostaining retinal sections from WT and RAMP2 KO mice for $\alpha$-SMA after LI-CNV revealed subretinal fibrosis to be present in both groups, although it was larger in RAMP2 KO mice 1659F11] (Figure 11A). Correspondingly, intense immunostaining for 1660 RhoA was detected in RAMP2 KO mice (Figure 11B). In flat mounts, ROCK1-positive areas were significantly larger in RAMP2 KO than WT mice (Figure 11, C and D). Gene expression analysis showed significant up-regulation of RhoA and ROCK1 in RAMP2 KO compared with WT mice (Figure 11E).

To further confirm the relationship between TGF- $\beta$, ROCK1, and CXCR4, the effect of the TGF- $\beta$ inhibitor, SB431542, and ROCK inhibitor, Y27632, on gene expression in LI-CNV samples was analyzed. It was observed that TGF- $\beta$ inhibition suppressed expression of the genes encoding ROCK1 and CXCR4, suggesting TGF- $\beta$ is up$1673_{\mathbf{F 1 2}}$ ] stream of both ROCK1 and CXCR4 (Figure 12A).
Similarly, ROCK inhibition suppressed expression of the gene encoding CXCR4, suggesting ROCK1 is upstream of CXCR4 (Figure 12B).

These data suggest that enhanced subretinal fibrosis in RAMP2 $\mathrm{KO}$ mice is associated with up-regulation of activity in the TGF- $\beta-$ ROCK1-CXCR4 pathway, and that inhibition of this pathway eliminates the difference in fibrosis between RAMP2 KO and WT.

\section{Discussion}

Currently, AMD patients are treated with photodynamic therapy, retinal photocoagulation, or anti-VEGF therapy. ${ }^{44}$ Among those, anti-VEGF therapy has good short-term results and is becoming a standard treatment for AMD. ${ }^{3-5}$ However, the beneficial effects of anti-VEGF drugs on the eye are time limited and require regular intravitreal injections. ${ }^{45}$ Furthermore, chronic usage of anti-VEGF therapy is becoming a subject of concern, as it may promote subretinal fibrosis. ${ }^{6-8}$ Clarifying more precisely the mechanism and molecular participants in subretinal fibrosis could potentially reveal novel candidates that could serve as the basis for new therapeutic approaches.

In that context, we focused on a bioactive peptide, AM, which was originally identified as a vasodilating and antihypertensive mediator that contributed to circulatory homeostasis. However, subsequent studies revealed that AM also possesses anti-oxidative, anti-inflammatory, antiapoptotic, and antifibrotic properties, and that it is present in the eyes. ${ }^{16}$ It has been speculated that AM could serve as a possible therapeutic agent for treatment of AMD. However, an important limitation of AM is its short half-life in the bloodstream, which limits its usefulness for treatment of chronic diseases. As an alternative, we propose that the AM receptor system could be a more useful target for the treatment of retinal vascular diseases. The complex of AM's receptor, CLR, with RAMP2 or RAMP3 has high affinity

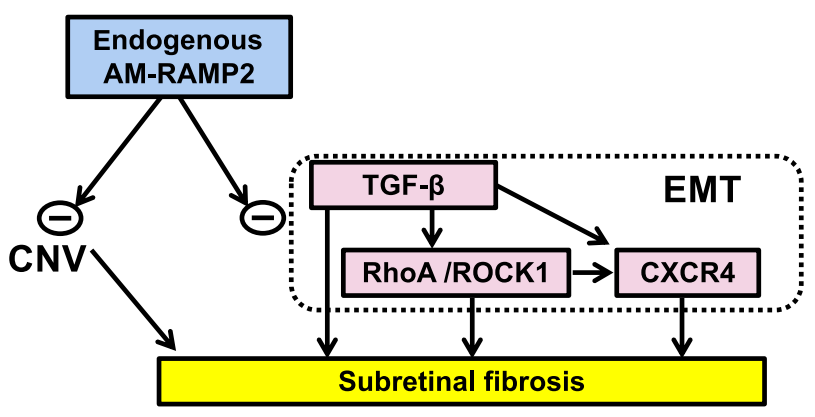

Figure 13 Proposed mechanism by which the adrenomedullin (AM)RAMP2 system suppresses subretinal fibrosis within laser-induced choroidal neovascularization (LI-CNV) lesions. Epithelial-mesenchymal transition (EMT) of retinal pigmental epithelial cells plays a crucial role in the progression of subretinal fibrosis within LI-CNV lesions. Downstream transforming growth factor- $\beta$ (TGF- $\beta$ ) signaling molecules, including RhoA-ROCK and CXCR4, promote EMT. The AM-RAMP2 system suppresses EMT and subretinal fibrosis by inhibiting EMT as well as CNV formation. 
for $\mathrm{AM}^{25}$ Moreover, the earlier finding that only homozygous RAMP2 KO die in utero of vascular abnormalities, similar to those observed in homozygous $\mathrm{AM} \mathrm{KO}^{26}$ mice, suggests RAMP2 is the key determinant of the vascular function of AM. In the present study, therefore, we focused on the AM-RAMP2 system and its actions in subretinal fibrosis associated with AMD.

In this study, LI-CNV size, fibrosis, and inflammation were exacerbated in AM KO and RAMP2 KO compared with their WT littermates. By contrast, no difference was found between RAMP3 KO and WT mice. This suggests that the beneficial effects of AM in LI-CNV were mediated via RAMP2 rather than RAMP3. In contrast to the findings with AM and RAMP2 KO, exogenous AM administration suppressed LI-CNV size, fibrosis, and inflammation. In the gene expression analysis, fibrosis-related molecules were up-regulated in AM KO and RAMP2 KO mice and downregulated in AM-administered mice. In fact, AM suppressed expression of some fibrosis-related molecules to levels below their baseline levels, which is consistent with the strong antifibrotic properties of AM. Ratio of $\alpha$-SMA-positive area/CNV area was not different in both AM KO and RAMP2 KO compared with WT mice, which may indicate that larger CNV accompanies with lager fibrosis, and suppression of $\mathrm{CNV}$ formation could potentially reduce the apparent levels of fibrosis.

Sakimoto et $\mathrm{al}^{46}$ used AM22-52 (a partial AM peptide that acts as a competitive antagonist of AM) and AM antibody in a similar LI-CNV model. They showed that intravitreal injection of AM22-52 or AM antibody reduced the size of the CNV. Their results appear to be opposite the present result obtained with AM KO mice, and we cannot be certain what accounts for the difference. However, one possibility is the difference in the methods used to suppress AM. Whereas Sakimoto et $\mathrm{al}^{46}$ used AM inhibitors, we used AM KO and RAMP2 KO mice. Moreover, Sakimoto et al ${ }^{46}$ intravitreally injected the inhibitors. In our experience, intravitreal injection, itself, affects the degree of CNV formation in mice. We therefore suggest the results of the present study more accurately reflect the role of endogenous AM. Indeed, using a similar LI-CNV model, Yuda et al ${ }^{19}$ showed that CNV is larger in AM KO than WT mice, which is consistent with the present findings. The limitation of using the LI-CNV model for studying retinal fibrosis is that it was evaluated up to 2 weeks, although pathology of fibrosis is in fact chronic in nature.

EMT is the process by which epithelial cells lose their adhesive function and transform into mesenchymal-like cells. It is known to be important in embryonic development, organogenesis, wound healing, and cancer invasion and metastasis. In addition, EMT has also been implicated in fibrosis, ${ }^{47}$ and is therefore a potential therapeutic target in fibrosis-related diseases. It was recently suggested that RPE cells are the cells mainly affected by EMT in subretinal fibrosis associated with AMD. ${ }^{48,49}$ In vitro, cellular stimulation with TGF- $\beta$ plus TNF- $\alpha$ has been used to induce
EMT. ${ }^{50,51}$ As a result of EMT, the epithelial cell markers Ecadherin, claudin-1, ZO-1, and cytokeratin-18 are all downregulated, whereas the mesenchymal markers $\alpha$-SMA, fibronectin, fibroblast-specific protein-1, vimentin, collagen 1 , and SM22 $\alpha$ are all up-regulated. ${ }^{50}$ In the present study, we induced EMT in ARPE19 cells, an RPE cell line, by exposing the cells to TGF- $\beta$ plus TNF- $\alpha$. Subsequent evaluation of ZO-1 and SM22 $\alpha$ levels confirmed that AM suppresses EMT in ARPE19 cells.

Using real-time PCR analysis, we found that expression level genes encoding TGF- $\beta$ and CXCR4 were elevated in $\mathrm{AM} \mathrm{KO}$ and RAMP2 KO mice and decreased by AM administration. TGF- $\beta$ has been identified as the main factor driving the inflammation and fibrosis associated with AMD in humans. ${ }^{52}$ On the other hand, AM has been shown to suppress expression of inflammatory cytokines, including TGF- $\beta$, by inhibiting phosphorylation of JNK, Q1 extracellular signal-regulated kinase, and p38 mitogenactivated protein kinase. ${ }^{53-55} \mathrm{CXCR} 4$ is thought to be a downstream target of TGF- $\beta .^{40,41}$ CXCR4 is well known as the receptor required for HIV to enter cells, ${ }^{56}$ and it is also reportedly involved in the formation of $\mathrm{LI}-\mathrm{CNV} .^{32,57}$ In recent years, CXCR4 has become an attractive target for the treatment of fibrosis in many organs, including the lung, ${ }^{58}$ heart, ${ }^{59}$ liver, ${ }^{60}$ and kidney, ${ }^{61}$ and CXCR4 inhibition using plerixafor suppresses fibrosis. Thus, the beneficial effects of the AM-RAMP2 system may be explained by suppression of the TGF- $\beta-$ CXCR4 pathway, although it is also possible that plerixafor can directly suppress CNV and fibrosis independent of AM-RAMP2 system. Although Smads have been identified as the canonical downstream targets of TGF- $\beta$, we detected no significant effect of AM on Smads.

To confirm that suppression of the TGF- $\beta-$ CXCR4 pathway explains the beneficial effects of the AM-RAMP2 system against subretinal fibrosis, we compared the effects of anti-TGF- $\beta$ or anti-CXCR4 agents in LI-CNV between RAMP2 KO and WT mice. Although both CNV and subretinal fibrosis were greater in RAMP2 KO than WT mice, inhibition of TGF- $\beta$ using SB431542 or inhibition of CXCR4 using plerixafor eliminated the difference between the responses in the two groups. This suggests up-regulation of activity in the TGF- $\beta-\mathrm{CXCR} 4$ pathway is the main cause of the enhanced pathologic features seen in RAMP2 $\mathrm{KO}$ mice.

We also found that levels of RhoA and ROCK1 expression were up-regulated in RAMP2 KO mice after induction of LI-CMV. The RhoA-ROCK1 pathway is known to be a downstream target of TGF- $\beta^{42}$ and is also reported to enhance EMT. ${ }^{43}$ ROCK inhibition using Y27632 blocked enlargement of the subretinal fibrotic area in RAMP2 KO mice, whereas gene expression analysis of LI-CNV samples suggested TGF- $\beta$ is upstream of both ROCK1 and CXCR4, and ROCK1 is upstream of CXCR4.

Figure 13 summarizes the actions of the AM-RAMP2 [F131858 system in subretinal fibrosis. EMT of RPE cells plays a 
crucial role in the progression of subretinal fibrosis in AMD. Downstream TGF- $\beta$ signaling molecules, including RhoAROCK and CXCR4, promote EMT. In addition to its suppression of CNV formation, the AM-RAMP2 system also suppresses EMT and subretinal fibrosis through inhibition of TGF- $\beta$, RhoA-ROCK, and CXCR4. We therefore propose that the AM-RAMP2 system has the potential to serve as a novel therapeutic target for suppression of subretinal fibrosis in the treatment of AMD.

\section{Supplemental Data}

Supplemental material for this article can be found at http://doi.org/10.1016/j.ajpath.2020.12.012.

\section{References}

1. Wong WL, Su X, Li X, Cheung CMG, Klein R, Cheng C-Y, Wong TY: Global prevalence of age-related macular degeneration and disease burden projection for 2020 and 2040: a systematic review and meta-analysis. Lancet Glob Health 2014, 2:e106-e116

2. Fine SL, Berger JW, Maguire MG, Ho AC: Age-related macular degeneration. N Engl J Med 2000, 342:483-492

3. Rosenfeld PJ, Shapiro H, Tuomi L, Webster M, Elledge J, Blodi B; MARINA and ANCHOR Study Groups: Characteristics of patients losing vision after 2 years of monthly dosing in the phase III ranibizumab clinical trials. Ophthalmology 2011, 118:523-530

4. Schmidt-Erfurth U, Kaiser PK, Korobelnik JF, Brown DM, Chong V, Nguyen QD, Ho AC, Ogura Y, Simader C, Jaffe GJ, Slakter JS, Yancopoulos GD, Stahl N, Vitti R, Berliner AJ, Soo Y, Anderesi M, Sowade O, Zeitz O, Norenberg C, Sandbrink R, Heier JS: Intravitreal aflibercept injection for neovascular age-related macular degeneration: ninety-six-week results of the VIEW studies. Ophthalmology 2014, 121:193-201

5. Group CR, Martin DF, Maguire MG, Ying GS, Grunwald JE, Fine SL, Jaffe GJ: Ranibizumab and bevacizumab for neovascular age-related macular degeneration. $\mathrm{N}$ Engl J Med 2011, 364: 1897-1908

6. Cohen SY, Oubraham H, Uzzan J, Dubois L, Tadayoni R: Causes of unsuccessful ranibizumab treatment in exudative age-related macular degeneration in clinical settings. Retina 2012, 32:1480-1485

7. Hwang JC, Del Priore LV, Freund KB, Chang S, Iranmanesh R: Development of subretinal fibrosis after anti-VEGF treatment in neovascular age-related macular degeneration. Ophthalmic Surg Lasers Imaging 2011, 42:6-11

8. Daniel E, Toth CA, Grunwald JE, Jaffe GJ, Martin DF, Fine SL, Huang J, Ying GS, Hagstrom SA, Winter K, Maguire MG: Comparison of Age-related Macular Degeneration Treatments Trials Research Group: Risk of scar in the comparison of age-related macular degeneration treatments trials. Ophthalmology 2014, 121:656-666

9. Schaal S, Kaplan HJ, Tezel TH: Is there tachyphylaxis to intravitreal anti-vascular endothelial growth factor pharmacotherapy in agerelated macular degeneration? Ophthalmology 2008, 115:2199-2205

10. Stramer BM, Mori R, Martin P: The inflammation-fibrosis link? a Jekyll and Hyde role for blood cells during wound repair. J Invest Dermatol 2007, 127:1009-1017

11. Kato J, Tsuruda T, Kita T, Kitamura K, Eto T: Adrenomedullin. Arterioscler Thromb Vasc Biol 2005, 25:2480-2487

12. Shimosawa T, Ogihara T, Matsui H, Asano T, Ando K, Fujita T: Deficiency of adrenomedullin induces insulin resistance by increasing oxidative stress. Hypertension 2003, 41:1080-1085

13. Brain SD, Grant AD: Vascular actions of calcitonin gene-related peptide and adrenomedullin. Physiol Rev 2004, 84:903-934
14. Iimuro S, Shindo T, Moriyama N, Amaki T, Niu P, Takeda N, Iwata H, Zhang Y, Ebihara A, Nagai R: Angiogenic effects of adrenomedullin in ischemia and tumor growth. Circ Res 2004, 95: 415-423

15. Shindo T, Kurihara $Y$, Nishimatsu H, Moriyama N, Kakoki M, Wang Y, Imai Y, Ebihara A, Kuwaki T, Ju KH, Minamino N, Kangawa K, Ishikawa T, Fukuda M, Akimoto $\mathrm{Y}$, Kawakami $\mathrm{H}$, Imai T, Morita H, Yazaki Y, Nagai R, Hirata Y, Kurihara H: Vascular abnormalities and elevated blood pressure in mice lacking adrenomedullin gene. Circulation 2001, 104:1964-1971

16. Udono-Fujimori R, Udono T, Totsune K, Tamai M, Shibahara S, Takahashi K: Adrenomedullin in the eye. Regul Pept 2003, 112:95-101

17. Imai $A$, Toriyama $\mathrm{Y}$, Iesato $\mathrm{Y}$, Hirabayashi $\mathrm{K}$, Sakurai $\mathrm{T}$, Kamiyoshi A, Ichikawa-Shindo Y, Kawate H, Tanaka M, Liu T, Xian X, Zhai L, Dai K, Tanimura K, Liu T, Cui N, Yamauchi A, Murata T, Shindo T: Adrenomedullin suppresses vascular endothelial growth factor-induced vascular hyperpermeability and inflammation in retinopathy. Am J Pathol 2017, 187:999-1015

18. Hirabayashi K, Tanaka M, Imai A, Toriyama Y, Iesato Y, Sakurai T, Kamiyoshi A, Ichikawa-Shindo Y, Kawate H, Tanaka M, Dai K, Cui N, Wei Y, Nakamura K, Iida S, Matsui S, Yamauchi A, Murata T, Shindo T: Development of a novel model of central retinal vascular occlusion and the therapeutic potential of the adrenomedullin-receptor activity-modifying protein 2 system. Am J Pathol 2019, 189:449-466

19. Yuda K, Takahashi H, Inoue T, Ueta T, Iriyama A, Kadonosono K, Tamaki Y, Aburatani H, Nagai R, Yanagi Y: Adrenomedullin inhibits choroidal neovascularization via CCL2 in the retinal pigmen epithelium. Am J Pathol 2012, 181:1464-1472

20. Iwase T, Nagaya N, Fujii T, Itoh T, Ishibashi-Ueda H, Yamagishi M, Miyatake K, Matsumoto T, Kitamura S, Kangawa K: Adrenomedullin enhances angiogenic potency of bone marrow transplantation in a rat model of hindlimb ischemia. Circulation 2005, 111:356-362

21. Hanabusa K, Nagaya N, Iwase T, Itoh T, Murakami S, Shimizu Y Taki W, Miyatake K, Kangawa K: Adrenomedullin enhances therapeutic potency of mesenchymal stem cells after experimental stroke in rats. Stroke 2005, 36:853-858

22. Nagaya N, Mori H, Murakami S, Kangawa K, Kitamura S: Adrenomedullin: angiogenesis and gene therapy. Am J Physiol Regul Integr Comp Physiol 2005, 288:R1432-R1437

23. Maki T, Ihara M, Fujita Y, Nambu T, Miyashita K, Yamada M, Washida K, Nishio K, Ito H, Harada $\mathrm{H}$, Yokoi $\mathrm{H}$, Arai $\mathrm{H}$, Itoh $\mathrm{H}$, Nakao K, Takahashi R, Tomimoto H: Angiogenic and vasoprotective effects of adrenomedullin on prevention of cognitive decline after chronic cerebral hypoperfusion in mice. Stroke 2011, 42:1122-1128

24. McLatchie LM, Fraser NJ, Main MJ, Wise A, Brown J, Thompson N, Solari R, Lee MG, Foord SM: RAMPs regulate the transport and ligand specificity of the calcitonin-receptor-like receptor. Nature 1998, 393:333-339

25. Shindo T, Tanaka M, Kamiyoshi A, Ichikawa-Shindo Y, Kawate H, Yamauchi A, Sakurai T: Regulation of cardiovascular development and homeostasis by the adrenomedullin-RAMP system. Peptides 2019, 111:55-61

26. Ichikawa-Shindo Y, Sakurai T, Kamiyoshi A, Kawate H, Iinuma N, Yoshizawa T, Koyama T, Fukuchi J, Iimuro S, Moriyama N Kawakami H, Murata T, Kangawa K, Nagai R, Shindo T: The GPCR modulator protein RAMP2 is essential for angiogenesis and vascular integrity. J Clin Invest 2008, 118:29-39

27. Yamauchi A, Sakurai T, Kamiyoshi A, Ichikawa-Shindo Y, Kawate H, Igarashi K, Toriyama Y, Tanaka M, Liu T, Xian X, Imai A, Zhai L, Owa S, Arai T, Shindo T: Functional differentiation of RAMP2 and RAMP3 in their regulation of the vascular system. J Mol Cell Cardiol 2014, 77:73-85

28. Kumar S, Berriochoa Z, Jones AD, Fu Y: Detecting abnormalities in choroidal vasculature in a mouse model of age-related macular degeneration by time-course indocyanine green angiography. J Vis Exp 2014, 84:e51061 
29. Hobara N, Goda M, Kitamura Y, Sendou T, Gomita Y, Kawasaki H Adrenomedullin facilitates reinnervation of phenol-injured perivascular nerves in the rat mesenteric resistance artery. Neuroscience 2007, 144:721-730

30. Uetake R, Sakurai T, Kamiyoshi A, Ichikawa-Shindo Y, Kawate H, Iesato Y, Yoshizawa T, Koyama T, Yang L, Toriyama Y, Yamauchi A, Igarashi K, Tanaka M, Kuwabara T, Mori K, Yanagita M, Mukoyama M, Shindo T: Adrenomedullin-RAMP2 system suppresses ER stress-induced tubule cell death and is involved in kidney protection. PLoS One 2014, 9:e87667

31. Davies MR, Liu X, Lee L, Laron D, Ning AY, Kim HT, Feeley BT: TGF-beta small molecule inhibitor SB431542 reduces rotator cuff muscle fibrosis and fatty infiltration by promoting fibro/adipogenic progenitor apoptosis. PLoS One 2016, 11:e0155486

32. Lyu Y, Xu WQ, Sun LJ, Pan XY, Zhang J, Wang YS: Effect of integrin alpha5beta1 inhibition on SDF-1/CXCR4-mediated choroidal neovascularization. Int J Ophthalmol 2018, 11:726-735

33. Zhang J, Liu W, Zhang X, Lin S, Yan J, Ye J: Sema3A inhibits axonal regeneration of retinal ganglion cells via ROCK2. Brain Res 2020, 1727:146555

34. Shimekake Y, Nagata K, Ohta S, Kambayashi Y, Teraoka H, Kitamura K, Eto T, Kangawa K, Matsuo H: Adrenomedullin stimulates two signal transduction pathways, cAMP accumulation and $\mathrm{Ca} 2+$ mobilization, in bovine aortic endothelial cells. J Biol Chem 1995, 270:4412-4417

35. Horio T, Kohno M, Kano H, Ikeda M, Yasunari K, Yokokawa K, Minami M, Takeda T: Adrenomedullin as a novel antimigration factor of vascular smooth muscle cells. Circ Res 1995, 77:660-664

36. Tanaka M, Koyama T, Sakurai T, Kamiyoshi A, IchikawaShindo Y, Kawate H, Liu T, Xian X, Imai A, Zhai L, Hirabayashi K, Owa S, Yamauchi A, Igarashi K, Taniguchi S, Shindo T: The endothelial adrenomedullin-RAMP2 system regulates vascular integrity and suppresses tumour metastasis. Cardiovasc Res 2016, 111:398-409

37. Peacock JG, Miller AL, Bradley WD, Rodriguez OC, Webb DJ, Koleske AJ: The Abl-related gene tyrosine kinase acts through p190RhoGAP to inhibit actomyosin contractility and regulate focal adhesion dynamics upon adhesion to fibronectin. Mol Biol Cell 2007, 18:3860-3872

38. Nieto MA, Huang RY, Jackson RA, Thiery JP: EMT: 2016. Cell 2016, 166:21-45

39. Kimura K, Orita T, Liu Y, Yang Y, Tokuda K, Kurakazu T, Noda T, Yanai R, Morishige N, Takeda A, Ishibashi T, Sonoda KH: Attenuation of EMT in RPE cells and subretinal fibrosis by an RAR- $\gamma$ agonist. J Mol Med (Berl) 2015, 93:749-758

40. Feng YF, Yuan F, Guo H, Wu WZ: TGF-beta1 enhances SDF-1induced migration and tube formation of choroid-retinal endothelial cells by up-regulating CXCR4 and CXCR7 expression. Mol Cell Biochem 2014, 397:131-138

41. Chen S, Tuttle DL, Oshier JT, Knot HJ, Streit WJ, Goodenow MM, Harrison JK: Transforming growth factor-betal increases CXCR4 expression, stromal-derived factor-1alpha-stimulated signalling and human immunodeficiency virus-1 entry in human monocyte-derived macrophages. Immunology 2005, 114:565-574

42. Fleming YM, Ferguson GJ, Spender LC, Larsson J, Karlsson S, Ozanne BW, Grosse R, Inman GJ: TGF-beta-mediated activation of RhoA signalling is required for efficient (V12)HaRas and (V600E) BRAF transformation. Oncogene 2009, 28:983-993

43. Hollanders K, Van Bergen T, Kindt N, Castermans K, Leysen D, Vandewalle E, Moons L, Stalmans I: The effect of AMA0428, a novel and potent ROCK inhibitor, in a model of neovascular agerelated macular degeneration. Invest Ophthalmol Vis Sci 2015, 56: $1335-1348$
44. Miller JW: Treatment of age-related macular degeneration: beyond VEGF. Jpn J Ophthalmol 2010, 54:523-528

45. Sawada O, Ohji M: Retinal vein occlusion. Dev Ophthalmol 2016, $55: 147-153$

46. Sakimoto S, Kidoya H, Kamei M, Naito H, Yamakawa D, Sakaguchi H, Wakabayashi T, Nishida K, Takakura N: An angiogenic role for adrenomedullin in choroidal neovascularization. PLoS One 2013, 8:e58096

47. Thiery JP, Sleeman JP: Complex networks orchestrate epithelialmesenchymal transitions. Nat Rev Mol Cell Biol 2006, 7:131-142

48. Ishikawa K, Kannan R, Hinton DR: Molecular mechanisms of subretinal fibrosis in age-related macular degeneration. Exp Eye Res 2016, 142:19-25

49. Hirasawa M, Noda K, Noda S, Suzuki M, Ozawa Y, Shinoda K, Inoue $\mathrm{M}$, Ogawa $\mathrm{Y}$, Tsubota $\mathrm{K}$, Ishida $\mathrm{S}$ : Transcriptional factors associated with epithelial-mesenchymal transition in choroidal neovascularization. Mol Vis 2011, 17:1222-1230

50. Yoshimatsu Y, Watabe T: Roles of TGF-beta signals in endothelialmesenchymal transition during cardiac fibrosis. Int J Inflam 2011, 2011:724080

51. Matoba R, Morizane Y, Shiode Y, Hirano M, Doi S, Toshima S, Araki R, Hosogi M, Yonezawa T, Shiraga F: Suppressive effect of AMP-activated protein kinase on the epithelial-mesenchymal transition in retinal pigment epithelial cells. PLoS One 2017, 12:e018148

52. Tosi GM, Orlandini M, Galvagni F: The controversial role of TGFbeta in neovascular age-related macular degeneration pathogenesis Int J Mol Sci 2018, 19:3363

53. Mandal J, Roth M, Papakonstantinou E, Fang L, Savic S, Tamm M, Stolz D: Adrenomedullin mediates pro-angiogenic and pro-inflammatory cytokines in asthma and COPD. Pulm Pharmacol Ther 2019, 56:8-14

54. Hu W, Shi L, Li MY, Zhou PH, Qiu B, Yin K, Zhang HH, Gao Y, Kang R, Qin SL, Ning JZ, Wang W, Zhang LJ: Adrenomedullin protects Leydig cells against lipopolysaccharide-induced oxidative stress and inflammatory reaction via MAPK/NF-kappaB signalling pathways. Sci Rep 2017, 7:16479

55. Wang Y, Zhang JS, Qian J, Huang GC, Chen Q: Adrenomedullin regulates expressions of transforming growth factor-beta 1 and beta1induced matrix metalloproteinase-2 in hepatic stellate cells. Int J Exp Pathol 2006, 87:177-184

56. Feng Y, Broder CC, Kennedy PE, Berger EA: HIV-1 entry cofactor: functional cDNA cloning of a seven-transmembrane, $\mathrm{G}$ proteincoupled receptor. Science 1996, 272:872-877

57. Lee E, Rewolinski D: Evaluation of CXCR4 inhibition in the prevention and intervention model of laser-induced choroida neovascularization. Invest Ophthalmol Vis Sci 2010, 51: 3666-3672

58. Chen Y, Yu X, He Y, Zhang L, Huang X, Xu X, Chen M, Chen X Wang L: Activation of $\mathrm{A}(2 \mathrm{a}) \mathrm{R}$ attenuates bleomycin-induced pulmonary fibrosis via the SDF-1/CXCR4 axis-related pathway. Am J Transl Res 2017, 9:4125-4136

59. Chu PY, Walder K, Horlock D, Williams D, Nelson E, Byrne M, Jandeleit-Dahm K, Zimmet P, Kaye DM: CXCR4 antagonism attenuates the development of diabetic cardiac fibrosis. PLoS One 2015, 10:e133616

60. Chow LN, Schreiner P, Ng BY, Lo B, Hughes MR, Scott RW, Gusti V, Lecour S, Simonson E, Manisali I, Barta I, McNagny KM, Crawford J, Webb M, Underhill TM: Impact of a CXCL12/CXCR4 antagonist in bleomycin (BLM) induced pulmonary fibrosis and carbon tetrachloride $(\mathrm{CCl} 4)$ induced hepatic fibrosis in mice. PLoS One 2016, 11:e0151765

61. Yuan A, Lee Y, Choi U, Moeckel G, Karihaloo A: Chemokine receptor Cxcr4 contributes to kidney fibrosis via multiple effectors. Am J Physiol Ren Physiol 2015, 308:F459-F472 